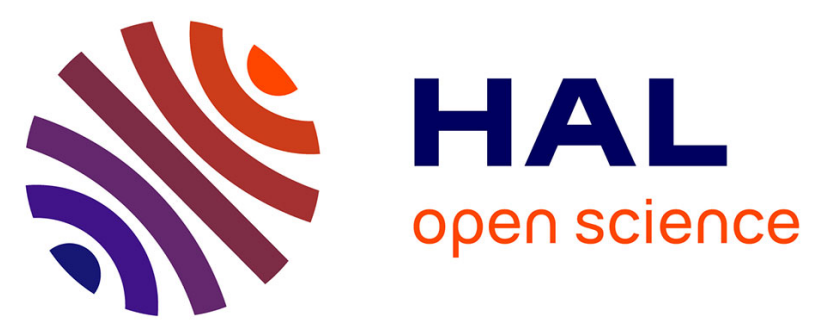

\title{
Age of metamorphism and deformation in the Montagne Noire dome (French Massif Central): Tapping into the memory of fine-grained gneisses using monazite $\mathrm{U}-\mathrm{Th}-\mathrm{Pb}$ geochronology
}

Francoise Roger, Christian Teyssier, Donna L. Whitney, Jean-Patrick Respaut, Jean-Louis Paquette, Patrice Rey

\section{To cite this version:}

Francoise Roger, Christian Teyssier, Donna L. Whitney, Jean-Patrick Respaut, Jean-Louis Paquette, et al.. Age of metamorphism and deformation in the Montagne Noire dome (French Massif Central): Tapping into the memory of fine-grained gneisses using monazite U-Th-Pb geochronology. Tectonophysics, 2020, 776, pp.228316. 10.1016/j.tecto.2019.228316 . hal-02948541

HAL Id: hal-02948541

https://hal.science/hal-02948541

Submitted on 29 Oct 2020

HAL is a multi-disciplinary open access archive for the deposit and dissemination of scientific research documents, whether they are published or not. The documents may come from teaching and research institutions in France or abroad, or from public or private research centers.
L'archive ouverte pluridisciplinaire HAL, est destinée au dépôt et à la diffusion de documents scientifiques de niveau recherche, publiés ou non, émanant des établissements d'enseignement et de recherche français ou étrangers, des laboratoires publics ou privés. 


\section{Journal Pre-proof}

Age of metamorphism and deformation in the Montagne Noire TEGTONOPHYSICS

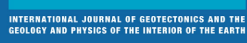

dome (French Massif Central): Tapping into the memory of finegrained gneisses using monazite $\mathrm{U}-\mathrm{Th}-\mathrm{Pb}$ geochronology

Françoise Roger, Christian Teyssier, Donna L. Whitney, JeanPatrick Respaut, Jean-Louis Paquette, Patrice F. Rey

PII: $\quad$ S0040-1951(19)30431-7

DOI: $\quad$ https://doi.org/10.1016/j.tecto.2019.228316

Reference: $\quad$ TECTO 228316

To appear in: $\quad$ Tectonophysics

Received date: $\quad 26$ July 2019

Revised date: $\quad 20$ December 2019

Accepted date: $\quad 26$ December 2019

Please cite this article as: F. Roger, C. Teyssier, D.L. Whitney, et al., Age of metamorphism and deformation in the Montagne Noire dome (French Massif Central): Tapping into the memory of fine-grained gneisses using monazite $\mathrm{U}-\mathrm{Th}-\mathrm{Pb}$ geochronology, Tectonophysics(2020), https://doi.org/10.1016/j.tecto.2019.228316

This is a PDF file of an article that has undergone enhancements after acceptance, such as the addition of a cover page and metadata, and formatting for readability, but it is not yet the definitive version of record. This version will undergo additional copyediting, typesetting and review before it is published in its final form, but we are providing this version to give early visibility of the article. Please note that, during the production process, errors may be discovered which could affect the content, and all legal disclaimers that apply to the journal pertain.

(C) 2020 Published by Elsevier. 


\section{Age of metamorphism and deformation in the Montagne Noire dome \\ (French Massif Central): Tapping into the memory of fine-grained gneisses using monazite $\mathrm{U}-\mathrm{Th}-\mathrm{Pb}$ geochronology}

Françoise Roger ${ }^{\mathrm{a},}{ }^{,}$, Christian Teyssier ${ }^{\mathrm{b}}$, Donna L. Whitney ${ }^{\mathrm{b}}$, Jean-Patrick Respauta, JeanLouis Paquettec, Patrice F. Rey ${ }^{\mathrm{d}}$.

a Laboratoire Géosciences Montpellier (CNRS-UMR 5243), Université Montpellier, Campus Triolet, 34095 Montpellier Cedex 5, France.

b Department of Earth and Environmental Sciences, University of Minnesota, Minneapolis MN 55455 USA.

c Laboratoire Magmas et Volcans (CNRS-UMR 6524), Campus Universitaire des Cézeaux, 63178 Aubière Cedex, France.

d School of Geosciences, University of Sydney, Sydney, NSW 2006, Australia.

* : Corresponding author : Françoise Roger (francoise.roger@umontpellier.fr) 


\section{Key Points}

- Monazite in fine-grained gneisses record late stages of high-T deformation.

- These late stages are related to exhumation of the Montagne Noire dome.

- Monazite U-Th-Pb dating of fine-grained gneisses yields 295 Ma ages.

- Fine-grained gneisses are up to $\sim 5 \mathrm{Myr}$ younger than the latest melt crystallization.

- Ages record localized, solid-state deformation, recrystallization, and fluid flow. 


\section{Abstract}

Recent work has revealed that the Montagne Noire dome, located in the foreland of the Variscan belt (French Massif Central), contains a record of nearly coeval, late Variscan eclogitization and migmatization. Given these new results, it is important to understand the chronology of events that produced high-grade metamorphism and exhumation. Using U-Th-Pb dating of monazite, this study confirms ages of $\sim 315-300$ Ma for high-T metamorphism in the augen gneiss that makes up a large fraction of the Montagne Noire dome, and documents for the first time $\sim 295$ Ma monazite ages in compositionally varied fine-grained gneisses that form folded continuous layers within the core of the dome. The fine-grained gneiss layers are intensely sheared and are interpreted to have localized late, high-T deformation in the core of the dome. These sheared fine-grained gneisses form a network of shear zones that were kinematically linked to the extensional and strike-slip deformation zones that exhumed the Montagne Noire dome in a pull-apart (s.l.) domain. Continued deformation-recrystallization and fluid flow within these shear zones likely drove rejuvenation of monazite for $\sim 5$ million years after much of the melt had crystallized in the Montagne Noire dome.

Keywords: Montagne Noire, France - Monazite U-Th- $\mathrm{Pb}$ dating - Fine grained gneisses - High-T deformation - Migmatite dome - Exhumation of partially molten crust 


\section{Introduction}

Migmatite domes are common in extensional settings such as regions where thickened crust has flowed during orogenic collapse or above retreating subduction zones. Evidence for the relationship of migmatite dome formation to lithospheric extension is the prevalence of domes in metamorphic core complexes, such as in the North American Cordillera and the Aegean region (e.g. Coney and Harms, 1984; Lister et al., 1994; Jolivet et al., 2004; Kruckenberg et al., 2011; Whitney et al., 2013). Nevertheless, there has been much debate about the significance of migmatite dome emplacement for the large-scale tectonic setting in which domes form, in part because dome formation is accompanied by complex deformation of ductile material, with deformation regime varying in time and space and also being influenced by strain rate, crustal thickness, and deep-crust viscosity, among other parameters (e.g., Rey et al., 2009a, b, 2017; Korchinski et al., 2018).

The Montagne Noire migmatite dome in the Variscan Massif Central, France, is an interesting case because (1) high-temperature metamorphism and dome emplacement occurred in the foreland of the orogen; and (2) there is evidence that strike-slip tectonics may have occurred during extension (e.g., transtension, or pull-apart; Roger et al., 2015). A critical aspect of understanding dome formation in this geodynamic context is the timing of dome formation, from initial high-pressure/high-temperature metamorphism and deformation in the deep crust to emplacement and subsequent deformation and cooling in the shallow crust. These events and associated processes have been documented in a series of recent studies focusing on migmatite, gneiss/schist, and granite (Roger et al., 2015; Fréville et al., 2016; Trap et al., 2017) as 
well as high-pressure mafic inclusions (eclogite) found in migmatite and gneiss (Demange, 1985) and have recorded a Variscan age of eclogitization ( $315 \mathrm{Ma}$, Whitney et al., 2015). It is well established that major decompression at high-temperatures occurred between $\sim 315-300$ Ma.

Late-stage tectonism in the Montagne Noire has been less well examined, including the timing of strike-slip deformation along the northern margin and its temporal relationship to metamorphism and deformation within the dome. Of particular interest is documenting the history of fine-grained gneiss (FGG) bodies and layers that occur within augen gneiss and migmatite in the dome and that may have localized this later deformation. In this paper, we apply U-Th-Pb geochronology on monazite within the FGG of the Montagne Noire. Our results are applicable to the general study of rapidly emplaced migmatite domes and the evolution of their deformation, including late-stage localization of strain not just in the bounding structures, but also in the internal domain of domes.

\subsection{Geologic overview of the Montagne Noire}

The Montagne Noire, at the southern edge of the Variscan French Massif Central, displays three main tectonostratigraphic units (Fig. 1): (1) a northern unit with SWdirected thrust sheets involving low-grade lower Paleozoic metasedimentary units; (2) a southern unit, the "Nappes du Versant Sud", in which slightly metamorphosed Paleozoic sedimentary units display km-scale, south-verging recumbent folds (Arthaud, 1970); and (3) a central unit (Axial Zone) mainly composed of migmatized orthogneiss (augen gneiss), anatectic granitoids, and layers of paragneiss. The internal structure of the Axial Zone delineates several subdomes, including the dominantly migmatitic Espinouse-Laouzas dome in the north and the Nore-Somail-Caroux suite of domes in the 
south (Fig. 1) (Rabin et al., 2015). The Axial Zone includes a carapace of Proterozoic to Ordovician metasedimentary rocks (Schistes X); thin layers of FGG, micaschist, marble/calc-silicate, and mafic to ultramafic units can be traced throughout the Axial Zone. Some layers contain mafic rocks displaying eclogite-facies assemblages (Demange, 1985; Faure et al., 2014; Whitney et al., 2015). The structural relations between the Axial Zone (dome core and schist carapace) and the southern and northern units (overlying thrust units) of the Montagne Noire have been debated for many decades.

The origin of the migmatitic Axial Zone itself has also been discussed considerably in the literature. Various mechanisms have been suggested for the emplacement of the Axial Zone rocks, in what appears to be the foreland of the Variscan orogen. Proposed mechanisms include (1) diapirism (Gèze, 1949; Schuilling, 1960; Faure and Cottereau, 1988; Faure et al., 2010), including diapiric rise during shortening (Beaud, 1985) or during gravitational collapse (Soula et al., 2001), (2) nappe stacking during contraction (Arthaud, 1970; Mattauer et al., 1996; Matte et al., 1998; Demange, 1999; Matte, 2007), possibly involving a significant component of erosion during dome exhumation (Malavieille, 2010; Malavieille and Konstantinoskaya, 2010), (3) dome development in a vertical strike-slip shear zone (Nicolas et al., 1977), (4) oblique extension and development of a metamorphic core complex after crustal thickening (Echtler and Malavieille, 1990; Van den Driessche and Brun, 1989, 1992; Brun and Van den Driessche, 1994, 1996; Franke et al., 2011), (5) syn-contractional gravitational collapse (Aerden, 1998; Aerden and Malavieille, 1999), and (6) extension-driven convergent flow leading to the formation of a "double dome" separated by a high-strain zone in the deep crust, coeval with overall extensional to transtensional tectonics in the upper crust (Rey et al., 2011, 2012, 2017), or following a phase of transpression (Rabin et al., 2015; 
Whitney et al., 2015). This overall double-dome structure is controversial for the eastern part of the Montagne Noire, where the southern (Caroux) dome is alternatively interpreted as a slab of high-strain augen gneiss (see comment and reply by Van Den Driessche and Pitra, 2012, and Rey et al., 2012).

\subsection{Overview of the Axial Zone}

The Montagne Noire Axial Zone (MNAZ) defines an elongate, sigmoidal dome that displays a complex internal structure, including subdomes and steep high-strain zones. The western termination of the Axial Zone consists of the Nore dome and a carapace of metasedimentary rocks (Demange, 1982; Rabin et al., 2015) (Fig. 1). At the eastern end of the dome the Espinouse and Caroux subdomes are dominated by more or less migmatized augen gneiss in antiforms that plunge eastward and are overlain by gneiss and schist units of biotite-chlorite grade (e.g., Roger et al., 2015). These two subdomes are separated by a tight synform of micaschist, the Rosis syncline (Fig. 2).

Metamorphic grade in the micaschist envelope has been documented in the eastern part of the Axial Zone (Bard and Rambeloson, 1973; Thompson and Bard, 1982; Fréville et al., 2016) and in the gneissic core (Schuiling, 1960, 1963; Schuiling and Widt, 1962; Den Tex, 1975; Demange, 1982; Soula et al., 2001). Mineral assemblages that include cordierite and sillimanite (+ andalusite in the schist carapace) indicate late low- $P$ high- $T$ conditions associated with the crystallization of widespread partially molten rocks and the emplacement of shallow, late Variscan granitoids, some cordieritebearing (e.g., the Vialais and Montalet granites) (e.g. Bogdanoff et al., 1984) (Fig.1). Following early work (Demange, 1985), eclogite-facies metamorphism has been investigated in mafic pods and blocks located in the western part of the Montagne Noire dome. Results suggest that some dome rocks may have been deeply buried and 
metamorphosed to eclogite facies at depths $>40 \mathrm{~km}$ just before migmatization and exhumation of the dome (Roger et al., 2015; Whitney et al., 2015).

In the eastern part of the Montagne Noire, the southern (Caroux) subdome is well exposed along the $\sim \mathrm{N}-\mathrm{S}$ section of the Gorges d'Héric (Fig. 2) and consists primarily of augen gneiss, with K-feldspar megacrysts several centimeters long. The augen gneiss typically has a well-defined foliation that can be traced around km-scale upright folds. The gneissic fabric is planar and linear in fold limbs and is dominantly linear (Ltectonite) in fold hinges, suggesting that folding and fabric development were at least in part synchronous. Foliation orientation varies according to position in the folds, and lineation is consistently oriented ENE-WSW, parallel to fold hinges.

In the Caroux subdome the augen gneiss is the host of FGG layers (up to a few tens of meters thick) that are also zones of concentrated strain, as shown by penetrative foliation and a high degree of stretching of minerals and layers (Fig. 2B, 3A). The FGG units can be mapped continuously on the scale of kilometers and are involved in kmscale folds defined by the augen gneiss main foliation (Fig. 2). The FGG is dominantly comprised of plagioclase-quartz-biotite gneiss, and hosts lithologically varied bodies such as calc-silicate and mafic and ultramafic pods, including amphibolite and eclogite (Faure et al., 2010, Whitney et al., 2015) (Fig. 2). These FGG units are the focus of a large part of the geochonological work reported here (Fig. 1; Table 1).

In the northern (Espinouse) subdome, augen gneiss occurs at the eastern periphery and is increasingly migmatitic structurally downward, toward the core of the dome. At deeper structural levels, augen gneiss has a layering that includes an increasing fraction of leucosome as well as garnet-bearing leucogranite bodies several tens of meters thick (Beaud, 1985), including the Vialais biotite granite; Bogdanoff, 1970; Roger et al., 2015). Whereas the migmatitic (metatexite) augen gneiss shows a well-developed foliation and 
lineation, the Vialais granite contains a weak magmatic foliation defined by the alignment of biotite grains and aggregates (Roger et al., 2015). Like in the Caroux subdome, the foliation of the Espinouse migmatite is folded around km-scale upright folds (Bogdanoff et al., 1984), although the foliation trajectories are more complex (Rabin et al., 2015).

The high melt-fraction (diatexite) migmatite that includes the Vialais granite is characterized by the common occurrence of quartz-sillimanite (fibrolite) nodules concentrated at the roof of the Vialais granite (Bogdanoff, 1970; Loueyit, 1978; Beaud, 1985; Brunel and Lansigu, 1997; Roger et al., 2015). The quartz-sillimanite nodules formed during crystallization of the Vialais granite and deformed during a strain increment involving vertical shortening and horizontal extension (Brunel and Lansigu, 1997). Significant deformation of the granite and migmatite ceased after this increment of deformation.

The migmatitic core of the Espinouse subdome and the high-temperature fabric of the Caroux augen gneiss are progressively overprinted upward by a nearly flat, meltpresent to solid-state fabric that grades into a mylonitic fabric and forms the carapace of the eastern termination of the dome (Fig. 1B). The metamorphic grade of this strong fabric decreases rapidly upward into the schist units (Schistes X units; Figs. 1B, 2A) in a manner similar to core complex detachment shear zones (Van den Driessche and Brun, 1989, 1991; Echtler and Malavieille, 1990; Brun and Van den Driessche, 1994, 1996). The northern and eastern margins of the Espinouse subdome as well as the eastern termination of the Caroux subdome consist of normal sense shear zones that have accommodated at least some of the Axial Zone exhumation (Fig. 1B). The timing of this extension event has been associated with deposition and deformation of the Late 
Carboniferous (Stephanian) Graissessac basin and has been dated by ${ }^{40} \mathrm{Ar} /{ }^{39} \mathrm{Ar}$ thermochronology at $297 \pm 3$ Ma (Maluski et al., 1991).

\subsection{Previous geochronological data}

The age of the augen gneiss protolith that makes up a large fraction of the Axial Zone has been determined at $\sim 520 \mathrm{Ma}$ and $\sim 470-450 \mathrm{Ma}$ using U-Th-Pb zircon dating (Ducrot et al., 1979; Roger et al., 2004, 2015; Cocherie et al., 2005; Faure et al., 2010; Pitra et al., 2012). The tectonic significance of these ages has been debated (e.g., Mattauer, 2004), but igneous bodies of Cambrian or Ordovician ages appear to be a common source for Massif Central migmatite (e.g. Alexandre, 2007; Bé Mezème et al., 2006; Melleton et al., 2010; Chelle-Michou et al., 2017).

In contrast, an increasingly large dataset of monazite ages points to prominent evidence of Variscan metamorphism and magmatism in the Axial Zone. For example, monazite dating of the Gorges d'Héric augen gneiss (Caroux subdome, Fig. 1) using the TIMS U-Th-Pb method reveals an age of $308 \pm 3$ Ma (Roger et al., 2015). A syntectonic meta-aplite dike from the Gorges d'Héric yielded an age of $309 \pm 3$ Ma based on U-Pb TIMS dating of zircon and monazite, (lower intercept for zircon fractions) and $313 \pm 1$ Ma (one concordant fraction of monazite) (Franke et al., 2011).

There has also been considerable debate over the age of anatectic granitoids as well as late, post-kinematic granites in the MNAZ. Faure et al. (2010) used electron microprobe analyses of monazite (U-Th-Pb chemical ages) to propose ages of 333-326 Ma for the former and 325 and 318 Ma for the latter. These results are consistent with the monazite age of $327 \pm 3 \mathrm{Ma}$ (U-Pb TIMS) that was previously published for the Vialais granite (Matte et al., 1998). However, more recent work using the LA-ICPMS and TIMS U-Th-Pb methods (Roger et al., 2015) has revealed much younger dates for both 
the Vialais granite $(303 \pm 4 \mathrm{Ma})$ and the post-kinematic Ourtigas leucogranite $(298 \pm 2$ Ma). These new dates are consistent with a recent extensive geochronological study (Trap et al., 2017) in which monazite from migmatite and granite bodies, as well as micaschist that mantle the Axial Zone was dated using LA-ICPMS. Results show that anatexis likely lasted from 315 to $300 \mathrm{Ma}$ and that contractional and extensional deformation were synchronous, and likely developed at different structural levels.

Younger ages of $294 \pm 1$ Ma (monazite) and $294 \pm 3$ Ma (zircon) have been reported for the syntectonic Montalet granite located at the northern margin of the Espinouse dome (Fig. 1) (U-Th-Pb LA-ICPMS method; Poilvet et al., 2011). The Saint-Eutrope orthogneiss, also located at the northern edge of the Espinouse dome, experienced intense shearing and mylonite development along an extensional detachment (Beaud, 1985), and yielded a U-Th-Pb LA-ICPMS monazite age of 295 Ma (Pitra et al., 2012). Recently, in the central part of the dome, the La Salvetat migmatite and the associated Laouzas anatectic granite were dated by the U-Th-Pb monazite LA-ICPMS method (Poujol et al., 2017). Two age groups were identified in both samples. Poujol et al. (2017) interpreted the first event, at $\sim 319 \mathrm{Ma}$, as a first stage of migmatization and as the emplacement age of the granite and the second event, at $\sim 298-295 \mathrm{Ma}$, which is also recorded by the muscovite ${ }^{40} \mathrm{Ar}-{ }^{39} \mathrm{Ar}$ system, as a likely fluid-induced event that is probably related to a second melting event identified through the emplacement of the Montalet and Vialais leucogranites.

Results from $\mathrm{K}-\mathrm{Ar}$ and ${ }^{40} \mathrm{Ar}-{ }^{39} \mathrm{Ar}$ geochronology studies further inform the cooling history of the Axial Zone and surrounding regions. K-Ar ages of muscovite from various localities in the Montagne Noire range from 297 to 292 Ma (Franke et al., 2011). Muscovite from sheared gneiss in the eastern (Caroux) and northern (Espinouse) margins of the Axial Zone yielded ${ }^{40} \mathrm{Ar}-{ }^{39} \mathrm{Ar}$ ages of $300 \pm 3 \mathrm{Ma}$ and $297 \pm 3 \mathrm{Ma}$, 
respectively (Maluski et al., 1991). Biotite in the same Caroux sample yielded an age of $316 \pm 4 \mathrm{Ma}$, substantially older than the muscovite age. Two samples of "banded gneiss" from the southern margin of the Caroux subdome yielded a muscovite age of $309 \pm 3 \mathrm{Ma}$ and a biotite age of $308 \pm 3$ Ma (Maluski et al., 1991). Fabric-forming muscovite extracted from a greenschist-facies Devonian marble in close proximity to the Caroux dome’s southern margin (Nappes du Flanc Sud) yielded an age of $297 \pm 3 \mathrm{Ma}$; this has been interpreted as the age of dynamic recrystallization at the base of the southern nappes during dextral shearing along the southern margin (Maluski et al., 1991).

Recent geochronology has also focused on eclogite bodies that occur within felsic gneiss of the Caroux subdome (Faure et al., 2014; Whitney et al., 2015). In the Whitney et al. (2015) study, a relatively unaltered eclogite was dated by U-Pb zircon (LA-ICPMS) at $\sim 315$ Ma (rims and most cores) and $\sim 360$ Ma (some zircon cores). Garnet rims record eclogite facies (high pyrope content, rutile inclusions). Because rare-earth element patterns for the $\sim 360$ Ma cores are consistent with crystallization of zircon with plagioclase, and for the $\sim 315$ Ma zircon are consistent with crystallization with garnet (among other evidence from garnet zoning and inclusions), the $~ 315 \mathrm{Ma}$ age was interpreted to represent the timing of eclogite-facies metamorphism (Whitney et al., 2015). If this interpretation is correct, the eclogite-facies metamorphism occurred not long before emplacement and low-pressure crystallization of migmatite and granite in the Axial Zone.

The geochronology results presented in this study complement this previous work and focuses on a suite of FGG that delineate the structure of the eastern margin of the Axial Zone. Results from additional samples of sheared augen gneiss and granite are also presented here in the context of the previous geochronology of similar rock units. 


\section{Sample descriptions}

In this study, we report new zircon and monazite $\mathrm{U}-\mathrm{Pb}$ dates from 14 samples that span deformation from high-temperature (melt-present) to solid-state conditions, including a suite of FGG samples that have not been the object of previous detailed geochronological work. Of the 14 samples, 10 are from the Caroux subdome, and 4 from the Espinouse subdome (Fig. 1B, Table 1).

Samples collected in the Caroux subdome include:

- Two samples of augen gneiss, one from the western region (Pont-de-Larn, MN 15) in the steep high-strain zone between the Caroux and Espinouse subdomes, and one from the eastern end of the Caroux subdome (Gouffre du Cerisier; MN14-03) (Fig. 1B). The latter augen gneiss is representative of the dominant lithology in the Caroux subdome. In previous work, zircon from MN 15 was dated by U-Pb (TIMS), and yielded Ordovician ages (456 $\pm 3 \mathrm{Ma}$ ) that were interpreted as the igneous emplacement age of the granitic protolith (Roger et al., 2004). In this paper, we report new results of monazite U-Pb analysis from this sample.

- Eight samples of fine-grained gneisses were sampled along the N-S stream that has carved the Gorges d'Héric (Fig. 2A and B). Two samples (MN11-59, -57) were collected in the Roc du Caroux, including one (59) in the vicinity of Héric; five were collected in the Gouffre du Cerisier area (MN11-47, -117, -118, -119, -121), and one in the Roc du Peyris (MN11-27) (Fig. 2). The Héric FGG contains biotite $\left(\mathrm{X}_{\mathrm{Fe}}=0.52\right)$, quartz, and plagioclase (An $20-22)$. Sample MN11-57 also consists of plagioclase, quartz, and biotite. Representative outcrop scale and thin section scale fabrics are shown in Fig. 3 A-C, using MN11-47 and MN11-59 as examples. The Gouffre du Cerisier samples have the following mineral assemblages: 
- MN11-117: reverse-zoned plagioclase (core: $\mathrm{An}_{25-26}$; rim: $\mathrm{An}_{33-39}$ ), quartz, biotite $\left(\mathrm{X}_{\mathrm{Mg}}=0.50\right)$, fibrolite;

- MN11-118: plagioclase $\left(\mathrm{An}_{32-34}\right)$, quartz, biotite $\left(\mathrm{X}_{\mathrm{Mg}}=0.40\right)$;

- MN11-119A: plagioclase, quartz, biotite, garnet, tourmaline;

- MN11-47 (migmatite): plagioclase ( $\mathrm{An}_{18-22}$ in the mesosome; $\mathrm{An}_{16-18}$ in the leucosome), quartz, biotite $\left(\mathrm{X}_{\mathrm{Mg}}\right.$ in mesosome $=0.46$; leucosome biotite is chloritized), garnet (inclusion-free, rounded grains in leucosome), fibrolite, and late muscovite;

- MN11-121: quartz, biotite $\left(\mathrm{X}_{\mathrm{Mg}}=0.51\right)$, and zoned plagioclase (including possible former augen and deformed leucosomes) with variable zoning; the most Na-rich compositions are $\mathrm{An}_{23}$ and the most Ca-rich are $\mathrm{An}_{36}$.

The Roc du Peyris sample (MN11-27) contains biotite $\left(\mathrm{X}_{\mathrm{Mg}}=0.50\right)$, quartz, reverse-zoned plagioclase (core: $\mathrm{An}_{23-25}$; rim: $\mathrm{An}_{26-29}$ ), and fibrolite; some plagioclase grains are tabular and resemble augen.

The four samples collected in the Espinouse subdome are:

- An augen gneiss (MN 5) from La Planésie, in the east-central part of the Espinouse (Fig. 1B);

- Three samples from the northern edge of the Espinouse subdome, where deformation has been linked to the normal ductile shear zone of the Espinouse fault (Brun and Van Den Driessche, 1996) or Mont de Lacaune fault (Demange et al., 1996) (Fig. 1B); these include:

- A sample of the syn-tectonic Montalet/Piquotalen granite (MN 28), collected at the Piquotalen Pass; this is a sheared, garnet-bearing, two-mica leucogranite with S-C structures interpreted to have developed during top-to-NE extensional 
shearing deformation (Brun and Van Den Driessche, 1996; Poilvet et al., 2011) associated with emplacement of the granite into the footwall of a normal, ductile shear zone (Poilvet et al., 2011).

- An augen gneiss (MN 27) from the area of the Saint-Eutrope Chapel and Murat sur Vèbre, along the northern border of the Axial Zone, where mylonitic bands are exhibited in the upper levels of gneiss. These mylonites have been interpreted to result from normal dextral strike slip and to record retrograde metamorphism relative to the sillimanite zone rocks of the dome core (Matte et al., 1998).

- A fine-grained gneiss (MN 4) collected near Murat sur Vébre (Candoubre finegrained gneiss). This gneiss consists of quartz, feldspar (mostly plagioclase, $\mathrm{An}_{17-23}$, with minor K-feldspar), biotite $\left(\mathrm{X}_{\mathrm{Mg}}=0.40\right)$, and minor garnet, sillimanite, muscovite and chlorite, with accessory zircon, monazite, and apatite.

\section{U-Th-Pb Geochronology}

\subsection{Instrumentation and analytical methods}

Monazite and zircon $\mathrm{U}-\mathrm{Th}-\mathrm{Pb}$ dating of these 14 samples was carried out using two analytical techniques: Isotopic Dilution Thermal Ionization Mass Spectrometry (IDTIMS) and Laser Ablation-Inductively Coupled Plasma Mass Spectrometry (LA-ICPMS). In this study, we present 14 new $\mathrm{U}-\mathrm{Th}-\mathrm{Pb}$ dates for monazite (some as grain mounts and some in thin section) and 1 new U-Pb date for zircon (MN 4) (Fig. 1; Table 1).

Monazite and zircon separates were obtained by standard crushing and heavy liquid and isodynamic magnetic separation techniques. Grains were handpicked under ethanol, and only the highest quality, crack-free grains were selected for analysis. Before analysis, backscatter electron (BSE) and cathodoluminescence (CL) images were 
acquired for all grains using a scanning electron microscope (SEM) in order to check spot positions with respect to the internal microstructures, inclusions, fractures and physical defects (Fig. 3 D and E; Fig. S1).

For the ID-TIMS analysis, single crystals of monazite were dissolved and analyzed at the University of Clermont-Auvergne (Laboratoire Magmas et Volcans) using the method described by Paquette and Pin (2001). Total blanks were 1-10 pg for Pb; U blanks were negligible. $\mathrm{U}$ and $\mathrm{Pb}$ isotopes were analyzed on a Fisons VG Sector 54-30 Mass Spectrometer in multi-collector static mode. Initial common $\mathrm{Pb}$ was determined for each fraction using the two-step model of Stacey and Kramers (1975). Analytical uncertainties are given in Table S1 (the supplementary material); individual fraction ellipses were determined using PbDat 1.24 software (Ludwig, 1993).

$\mathrm{U}-\mathrm{Th}-\mathrm{Pb}$ geochronology of zircon and monazite was also conducted by LA-ICPMS at Clermont-Ferrand. The analyses involved ablation of grains with a Resonetics Resolution M-50 powered by an ultra short pulse ATL Atlex Excimer laser system operating at a wavelength of $193 \mathrm{~nm}$. The detailed analytical procedures are described in Paquette et al. (2014) and detailed in Hurai et al. (2010) and in the supplementary material (Table S2). Data reduction was carried out with the GLITTER $₫$ software package from Macquarie Research Ltd (van Achterbergh et al., 2001)

For both techniques, dates and diagrams were generated using the Isoplot/Ex v. 2.49 software package (Ludwig, 2001). In the text and figures, all uncertainties in dates are given at $\pm 2 \sigma$. The decay constants used for the U-Pb system are those determined by Jaffey et al. (1971) and recommended by the IUGS (Steiger and Jäger, 1977).

Monazite data by LA-ICPMS were plotted in a U-Th-Pb concordia diagram $\left({ }^{206} \mathrm{~Pb} /{ }^{238} \mathrm{U}\right.$ vs $\left.{ }^{208} \mathrm{~Pb} /{ }^{232} \mathrm{Th}\right)$ because ${ }^{232} \mathrm{Th}$ measurement is more accurate than ${ }^{235} \mathrm{U}$. 


\subsection{U-Th-Pb Results}

In the following sections, we report the results of ID-TIMS and LA-ICPMS dating of zircon and/or monazite for 14 samples collected in the MNAZ and in lithologies including a deformed granite from the Espinouse subdome, as well as augen gneiss and FGG from both subdomes (Table 1).

\subsubsection{Espinouse subdome}

Monazite was separated and dated from sheared granite and augen gneiss samples (MN 28, MN 27, MN 5), and both zircon and monazite were analyzed from one sample of FGG (MN 4).

\subsubsection{Sheared granite}

In the sheared Montalet granite from Piquotalen (MN 28; Fig. 1B), monazite grains were analyzed by LA-ICPMS. Monazite grains are yellow, transparent, unzoned and euhedral. Sixteen spot analyses were carried out on 13 grains (Table S3). Age data for rims and cores of three monazite grains $(\# 2,3,19)$ are similar. Results for the 16 grains yield a concordia age of $298.5 \pm 1.8 \mathrm{Ma}(\mathrm{MSWD}=0.8 ; \mathrm{N}=16$ ) (Fig. 4 ).

\subsubsection{Augen gneiss}

Monazite grains from augen gneiss MN 27, collected at the northern margin of the Espinouse subdome (Saint-Eutrope) (Fig. 1B), were analyzed by LA-ICPMS. Monazite grains are small to moderate size $(>200 \mu \mathrm{m})$, yellow, transparent, and anhedral. BSE and CL images show mostly homogeneous (unzoned) grains. Seventeen spot analyses were carried out on 15 monazite grains. All results give a concordia age of $314.4 \pm 1.6$ Ma (MSWD = 4.2; N=17) (Table S3; Fig. 5A). 
Three monazite grains from the La Planésie augen gneiss (MN 5) were analyzed by ID-TIMS (Table S1). In the concordia diagram, the 3 points are concordant to subconcordant. Analytical point \#2 is interpreted to result from low U loss $(<1 \%)$. A linear regression of these three points gives a date of $304.5 \pm 1$ Ma for the upper intercept, and $67 \pm 44 \mathrm{Ma}$ for the lower intercept (MSWD=0.7) (Fig. 5B).

\subsubsection{Fine-grained gneiss}

Both zircon and monazite were analyzed from the Candoubre FGG (MN 4) (Fig. 1B). Thirty-three LA-ICPMS spots on both core and rim of 17 zircon grains were analyzed (Table S3). CL images show that most zircons have complex internal structures, with distinct cores surrounded by regions of oscillatory zoning (Fig. S1A). Twenty-six spots are concordant or subconcordant, yielding a range of dates from $\sim 285$ to $760 \mathrm{Ma}$, with the exception of spot \#45, which is around 1.9 Ga (Table S4, Fig. 6). The seven discordant data (spots \#8, 9, 12, 23, 35, 40,44) were not taken into consideration in the interpretation of dates. The ${ }^{206} \mathrm{~Pb} /{ }^{238} \mathrm{U}$ dates histogram of the concordant to subconcordant data shows the presence of three major populations at $\sim 300-310 \mathrm{Ma}$ (group 1), 540-600 Ma (group 2), and 640-700 Ma (group 3) (Fig. 6):

- Group 1 dates were obtained from the rims of six zircons (spots \#8, 23, 24, 28, 33, 40). These rims are characterized by low Th concentrations ranging from 2 to $9 \mathrm{ppm}$, with very low Th/U from 0.01 to 0.02 , values typical of non-magmatic zircon $(<0.1)$ (i.e. metamorphic, recrystallized, or hydrothermal) (Tiepel et al., 2004). These zircon rims yield ${ }^{206} \mathrm{~Pb} /{ }^{238} \mathrm{U}$ dates between $339 \pm 8 \mathrm{Ma}$ and $282 \pm 6$ Ma (Fig. 6, Table S4), and among these points, three are concordant $(\# 24,28,33)$ and yield a concordia age of $290 \pm 9$ Ma (MSWD = 4) (Fig. 6). These six zircons all have inherited cores: two are concordant at $\sim 580-600$ Ma (spots \#7, 41), two 
others are concordant at $\sim 640-650$ Ma (spots \#22, 29), and the other two are concordant at $\sim 700$ and $760 \mathrm{Ma}$, respectively (spot \#25, 32) (Fig. 6, Table S4).

- Group 2 dates were determined from eight spots (\#7, 13,14, 21, 30, 41, 42, 43) that have Th/U ratios (0.43-0.87) typical of magmatic zircon, with the exception of the rim of zircon 5 (spot \#13), which has a low Th/U ratio of 0.04 . These eight concordant analyses yield a concordia age of $579 \pm 12$ Ma (MSWD $=2.3$ ). The rim of zircon 16 (spot \#20) is concordant at $\sim 540 \mathrm{Ma}$, and its $\mathrm{Th} / \mathrm{U}$ ratio $(=0.41$ ) is also typical of magmatic zircon (Table S4; Fig. 6). The difference in date of $\sim 40$ My between this point and the average age of group 2 may be the result of radiogenic $\mathrm{Pb}$ loss. The concordant date of $371 \pm 8 \mathrm{Ma}$ determined for the rim of zircon 45 (spot \#31) is probably meaningless because it corresponds to a mixture between an old ( $\sim 580 \mathrm{Ma})$ core (spot \#30) and a younger rim (probably $\sim 290-300 \mathrm{Ma})$.

- Group 3 dates were determined for eight concordant spots (\#10,11, 18, 19, 22, $29,38,39)$ that yield a concordia age of $646 \pm 8$ Ma (MSWD $=0.75 ; N=6)$. These points have $U$ concentrations between 70 and $300 \mathrm{ppm}$ and $\mathrm{Th} / \mathrm{U}$ ratios from 0.41 to 1.03 that are typical of an igneous origin. Zircon 52 has an inherited magmatic core $(\mathrm{Th} / \mathrm{U}=0.83)$ concordant at $1.95 \mathrm{Ga}($ spot \#45) and a younger rim (probably 290-300 Ma). Spot \#44 is a mixture between these two constituents; in fact, linear regression of the results for spots \#44 and 45 yields a lower intercept of $260 \pm 32 \mathrm{Ma}$..

The Candoubre FGG (MN 4) also contains monazite that was analyzed by ID-TIMS. Four single monazite grains were analyzed (Table S1). Results are concordant or slightly discordant. A linear regression of these four points gives a date of $301 \pm 7 \mathrm{Ma}$ for the upper intercept and $0 \pm 25 \mathrm{Ma}$ for the lower intercept $(\mathrm{MSWD}=5.4)$. The 
weighted average of the ${ }^{207} \mathrm{~Pb} /{ }^{206} \mathrm{~Pb}$ is $299 \pm 8 \mathrm{Ma}(\mathrm{MSWD}=5.9 ; \mathrm{N}=4$ ) (Fig. $5 \mathrm{C}$ ).

\subsubsection{Caroux subdome}

Monazite from the Caroux subdome augen gneiss was separated and dated by IDTIMS for sample MN 15, and by LA-ICPMS for sample MN14-03. Monazite from the FGG was analyzed by LA-ICPMS either on separated grains (samples MN11-59, MN11-57, MN11-117, MN11-118, MN11-121, MN11-27), or in situ on crystals within a thin section (sample MN11-119A). Monazite from sample MN11-47 was dated by both techniques.

\subsubsection{Augen gneiss}

Three monazite grains were analyzed by the ID-TIMS method for the Pont de Larn augen gneiss (MN 15) of the western Caroux subdome (Fig. 1B, Table S1). The Pb and U contents are heterogeneous: e.g., $\mathrm{Pb}$ contents range between 728 ppm and 2175 ppm (Table S1). In the concordia diagram, the three points are concordant at $\sim 310$ and 312 Ma (Fig. 7A). The concordia age is $311.8 \pm 0.5 \mathrm{Ma}(\mathrm{MSWD}=1.8)$.

Monazite grains from the Gouffre du Cerisier (Gorges d'Héric) augen gneiss (MN1403) of the eastern Caroux subdome are of moderate size (100-200 $\mu \mathrm{m})$, yellow, transparent and euhedral to sub-euhedral. BSE images show a slight zoning (Fig. S1B). In term of composition, there are two populations: a major population (14 grains) that has high $\mathrm{ThO}_{2}(4-7 \%), \mathrm{La}_{2} \mathrm{O}_{3}(\sim 11 \%)$ and $\mathrm{Ce}_{2} \mathrm{O}_{3}(\sim 25-27 \%)$ and low $\mathrm{Y}_{2} \mathrm{O}_{3}(2.5-4 \%)$ and $\mathrm{Dy}_{2} \mathrm{O}_{3}(0.5-1 \%)$. The smaller population, probably xenotime, (4 grains: Mo6, 11, 18, 27) is characterized by low $\mathrm{ThO}_{2}(<0.5 \%), \mathrm{La}_{2} \mathrm{O}_{3}(<0.1 \%)$ and $\mathrm{Ce}_{2} \mathrm{O}_{3}(<0.1 \%)$, and high $\mathrm{Y}_{2} \mathrm{O}_{3}(\approx 39-42 \%)$ and $\mathrm{Dy}_{2} \mathrm{O}_{3}(\approx 4-5 \%)$ contents. Twenty spots on 14 monazite grains of the major Th-rich population were analyzed (Table S3). They are characterized by a high $\mathrm{Th} / \mathrm{U}$ ratio (4.6-7.2). In the concordia diagram, all the ellipses are concordant, and 
the concordia age is $314.1 \pm 1.3 \mathrm{Ma}$ (Fig. 7B). For the lower-Th (Y-rich) population, eight spots on 4 grains were analysed. Their Th/U ratios are ranging between 0.1 and 0.4 . Every crystal was dated using two different analytical spots. For every grain, both analyses show similar dates and $\mathrm{Pb}, \mathrm{U}$ and Th concentrations (Table S3). One crystal is concordant at $~ 510-520$ Ma (Mo 11), and three grains (Mo6, Mo18 and Mo27) form two concordant clusters yielding concordia ages of $333.0 \pm 5.5 \mathrm{Ma}(\mathrm{MWSD}=2.1 ; \mathrm{N}=4)$ and $349.4 \pm$ 4.7 Ma (MSWD =2.5; N=2) (Fig. 7B; Table S3). These results may correspond to an analytical mixture between an old component (520 Ma) and a younger Variscan component (possibly 340 Ma, but more likely 314 Ma).

\subsubsection{Fine-grained gneisses}

Analyses on separated grains

Monazite grains in three samples (MN11-59, MN11-57, MN11-121) are small (50$100 \mu \mathrm{m})$, yellow, transparent, and anhedral. BSE images show a mostly homogeneous structure (no or slight zoning). For every sample, ten or eleven separate crystals of monazite were analyzed (Table S3; Figs. 8A, B and 9A). Age data for rims and cores of monazites are similar (Table S3). All spots are concordant or sub-concordant at $\sim 295$ Ma. The monazite grains of samples MN11-59 and MN11-57 yield concordia ages of $294.3 \pm 2.2 \mathrm{Ma}(\mathrm{MSWD}=0.97 ; \mathrm{N}=14)$ and $290.6 \pm 2.4 \mathrm{Ma}(\mathrm{MSWD}=1.5 ; \mathrm{N}=15)$, respectively (Fig. 8A, B). Monazite grains of sample MN11-121 give a weighted average of the ${ }^{208} \mathrm{~Pb} /{ }^{232} \mathrm{Th}$ date of $294.9 \pm 2.9 \mathrm{Ma}(\mathrm{MSWD}=2.2 ; \mathrm{N}=22$ ) (Fig. 9A).

In sample MN11-27, monazite grains are small (50-100 $\mu \mathrm{m})$, brown, transparent, and anhedral or rounded. BSE images show a thin rim (?10 $\mu \mathrm{m})$ for some crystals. Twenty-four spot analyses were carried out on 12 isolated grains. All but one (Mo3-r) 
spot analysis are concordant between 280 Ma and 360 Ma (Fig. 8C). Among these analyses, 17 (11 cores, 6 rims) form a concordant cluster that yields a concordia age of $294.6 \pm$ 1.6 Ma (MSWD = 0.86).

In samples MN11-117 and MN11-118 the crystals are homogeneous, without internal structure. Sample MN11-118 yielded only 4 crystals. All analyses (4 per crystal) are concordant and give a concordia age of $441 \pm 2.5 \mathrm{Ma}(\mathrm{MSWD}=1.09 ; \mathrm{N}=16$ ) (Fig. 9B, Table S3). In sample MN11-117, 13 monazite crystals were analyzed. All the analytical points plot in a concordant position between 400 and 460 Ma (Fig. 9C). Among these analyses, 18 yield a mean ${ }^{208} \mathrm{~Pb} /{ }^{232} \mathrm{Th}$ date of $445.8 \pm 3.8(\mathrm{MSWD}=1.3)$.

Isolated monazite crystals in sample MN11-47 are yellow with a size of $\sim 200 \mu \mathrm{m}$. They are typically homogeneous but the BSE images of some grains show a thin rim (?10-15 $\mu \mathrm{m}$ ) (Fig. S1C). Twenty-two spots on 14 grains were analyzed (Table S3). With the exception of the analysis of the rim of monazite grain Mo8, all the analyses have a concordant to sub-concordant position between 455 and 330 Ma. Among these analyses, 14 (9 cores, 5 rims) form a concordant cluster yielding a concordia age of $431.0 \pm 2.5 \mathrm{Ma}(\mathrm{MSWD}=1.4)$ (Fig. 9D).

\section{In-situ analyses in thin section}

Six monazite crystals in sample MN11-47 were also analyzed in situ within a thin section. They show a slight zoning and can be either included in biotite (Mo3, Mo4) or present in the quartzo-feldspathic matrix (Mo2, Mo5, Mo6) or forming a clast $(\sim 100$ $\mu \mathrm{m})$ (Mo1) (Fig. 3D; Table S3). Three small-size $(<40 \mu \mathrm{m})$ grains (Mo2, Mo3, Mo4) are elongated with a shape ration up to $4: 1$. The monazite Mo6 is sub-euhedral with a $\sim 50$ $\mu \mathrm{m}$ size. All results are concordant and display two distinct populations: one at $\sim 450$ Ma and one at $\sim 300 \mathrm{Ma}$ (Fig. 9E). The older population consists of 4 grains (Mo1, Mo2, 
Mo5 and Mo6). Seven spots (7/8 spots) analyzed on 3 grains (Mo1, Mo5, Mo6) yield a concordia age of $450.6 \pm 5.6 \mathrm{Ma}(\mathrm{MSWD}=0.94)$. The younger population consists of four spots on 2 grains (Mo2, Mo3) and displays a concordant younger cluster yielding a concordia age of $301 \pm 4$ Ma (MSWD = 1.04) (Fig. 9E). No correlation is observed between the textural position of the populations (e.g., inclusion vs. matrix) and the dates (Fig. 3D). Results of all monazite analyses obtained on grain mounts (Fig. 9D) and in thin section (Fig. 9E) confirm the presence of two distinct populations at $439.7 \pm 5.1$ $\mathrm{Ma}(\mathrm{N}=22)$ and at $301 \pm 4.3 \mathrm{Ma}(\mathrm{N}=4)$ (Fig. 9F).

For MN11-119A, 16 monazite crystals were analyzed in situ on a thin section. Monazite grains occur either as inclusions in biotite (Mo4, Mo5, Mo7, Mo8, Mo9, Mo11, Mo12) and feldspar porphyroblasts (Mo1, Mo2, Mo3, Mo13), or in the matrix (Mo6, Mo10, Mo14, Mo15, Mo16) (Fig. 3E). In the concordia diagram, the 23 analytical points (inclusions and matrix) are concordant between 290 and 330 Ma. They can be divided into two populations: one at $\sim 295-300 \mathrm{Ma}$ and a second at $\sim 320$ Ma (Fig. 9G). The major population consists of 17 spots and yields a concordia age of $297.3 \pm 1.6 \mathrm{Ma}$ $(M S W D=1.06)$. The six other analyses were measured on 5 grains that are included either in biotite (Mo5, Mo7, Mo11) or in feldspar porphyroblasts (Mo2, Mo3). They display a concordant older cluster yielding a mean ${ }^{208} \mathrm{~Pb} /{ }^{232} \mathrm{Th}$ date of $316.9 \pm 5.5$ $(\mathrm{MSWD}=1.4)$. Among the 16 crystals analyzed, two are heterogeneous grains (Mo2 and Mo5) that present both dates. No correlation is observed between the textural position of the populations (e.g., inclusion vs. matrix) and the dates.

\section{Interpretation of geochronology results}

\subsection{Ages of fine-grained gneisses (U-Th-Pb geochronology)}




\subsubsection{Zircon dating}

The new zircon data obtained by LA-ICPMS for the Candoubre fine-grained gneiss (MN 4) show complex spectra with ages ranging between $1.9 \mathrm{Ga}$ and $300 \mathrm{Ma}$. The Th/U ratio values and the concordant position of the analytical points suggest that the Candoubre FGG contains detrital zircon grains derived from multiple magmatic sources (1.9 Ga, 760-700 Ma, $650 \mathrm{Ma}, 580 \mathrm{Ma}$ ) (Fig. 6). The presence of Paleoproterozoic and Neoproterozoic inherited zircons has also been recognized in the Cambro-Ordovician orthogneisses and in the metasedimentary rocks from the Limousin area, the Massif Central, and the Pyrenees with a possible source region that could be the West African craton (Gebauer et al., 1988; Cocherie et al., 2005; Melleton et al. 2010). The Candoubre FGG was later metamorphosed to upper amphibolite conditions during the Variscan event at around $300 \mathrm{Ma}$ (Fig. 6).

\subsubsection{Monazite dating}

This study focused primarily on monazite $\mathrm{U}-\mathrm{Th}-\mathrm{Pb}$ dating. Monazite is known to preserve the age of its crystallization because it is not sensitive to $\mathrm{Pb}$ diffusion (e.g. Seydoux-Guillaume et al., 2002; Cherniak et al., 2004; Gardès et al., 2007) and can record successive high-temperature events (Pyle and Spear, 2003; Finger and Krenn, 2007; Didier et al., 2014). However, monazite recrystallizes readily by dissolution/precipitation processes when fluids or melts are involved (Bosse et al., 2009; Williams et al., 2011; Tartèse et al., 2012; Kelly et al., 2012; Didier et al., 2013), and is therefore useful for dating high-temperature deformation/recrystallization.

The U-Th-Pb ages of the studied FGG of the MNAZ point to two main episodes of monazite growth, one of Ordovician age (440-450 Ma), and the other of Variscan age (300-290 Ma) (Table 1, Figs. 5C, 8 and 9). These two events are likely to coincide with 
two main metamorphic/orogenic events, in agreement with the available U-Th-Pb data for the Montagne Noire (Roger et al., 2004, 2015; Cocherie et al., 2005; Poilvet et al., 2011; Faure et al., 2010; Pitra et al., 2012; Poujol et al., 2017; Trap et al., 2017). Our results may be divided into three groups:

i) FGG containing only monazite of Ordovician age. In the Gouffre du Cerisier (Caroux subdome), monazite data from samples MN11-117 and MN11-118 plot in a single cluster around $445 \mathrm{Ma}$ in ${ }^{206} \mathrm{~Pb} /{ }^{238} \mathrm{U}$ versus ${ }^{208} \mathrm{~Pb} /{ }^{232} \mathrm{Th}$ concordia diagrams, yielding a mean ${ }^{208} \mathrm{~Pb} /{ }^{232} \mathrm{Th}$ date of $445.8 \pm 3.8 \mathrm{Ma}$ and the concordia age of $441.0 \pm 2.5$ Ma, respectively (Table 1; Figs. 2, 9B, 9C). This Ordovician event is well documented in the MNAZ and interpreted as the emplacement age of the magmatic protolith of the augen gneisses that form the bulk of the Caroux and Espinouse subdomes (Roger et al., 2004, 2015; Cocherie et al., 2005; Faure et al., 2010; Pitra et al., 2012; Trap et al., 2017).

ii) samples containing monazites of both Ordovician and Variscan ages. The monazite grains from sample MN11-47, also located in the Gouffre du Cerisier, plot in two distinct clusters. The oldest cluster at $\sim 440-450 \mathrm{Ma}$, with a concordia age of $450.6 \pm$ 5.6 Ma for 7 older concordant data. The second one around $\sim 300 \mathrm{Ma}$ is given by a concordia age of $301 \pm 4$ Ma obtained for four analyses performed in two monazite grains (Table 1; Figs. 2, 9D, 9E, 9F). For the monazite grains dated in thin section, no correlation is observed between the textural position of the Ordovician and Variscan monazites (e.g., inclusion, matrix) and the dates (Fig. 9E). The other concordant dates between these two clusters constituted mainly by rims analysis, may correspond to an analytical mixture between an old Ordocivian component (450Ma) and a younger thin rim that is a likely Variscan component (300 Ma) (Fig. 9D). The Ordovician monazites 
were not altered or erased, confirming that monazite is highly resistant to hightemperature processes (Didier et al., 2014). The migmatization of Caroux orthogneiss that occurred between $\sim 315$ and 300 Ma involves prograde conditions at $680 \pm 50{ }^{\circ} \mathrm{C}$ and 0.7-0.8 \pm 0.1 GPa (Roger et al., 2015; Fréville et al., 2016; Trap et al., 2017).

iii) samples containing only Variscan monazites. The monazites of some FGG from the Caroux (MN11-27; MN11-121; MN11-57; MN11-59) or Espinouse (MN 4) domes yield Variscan ages of crystallization between 300 and $290 \mathrm{Ma}$, with a cluster around 295 Ma (Table 1; Figs. 1B, 5C, 8, 9A). Similarly, the Candoubre FGG (MN 4) displays nonmagmatic concordant zircon rims $(\mathrm{Th} / \mathrm{U}=0.01-0.02)$ that appear to be younger than $300 \mathrm{Ma}$, confirming the imprint of this late Variscan event (Fig. 6). The concordant dates for sample MN11-27 between $300 \mathrm{Ma}$ and $360 \mathrm{Ma}$ and older than the concordia age of $294.6 \pm 1.6$ Ma confirm the occurrence of an analytical mixture between an old component (probably $450 \mathrm{Ma}$ or $520 \mathrm{Ma}$ ) and a younger Variscan component (Fig. 8C). The atypical sample MN11-119A from the Gouffre du Cerisier yields two Variscan age groups. One group at $\sim 295-300 \mathrm{Ma}$ is given by a concordia age of $297.3 \pm 1.6 \mathrm{Ma}$, and another less abundant group clusters around $\sim 315-320 \mathrm{Ma}$, with a mean ${ }^{208} \mathrm{~Pb} /{ }^{232} \mathrm{Th}$ date of 316.9 \pm 5.5 Ma (Fig. 9G).

Monazite may (re)-crystallize owing to fluid-rock interaction relatively late in the metamorphic history (e.g. Bosse et al. 2009; Tartèse et al., 2012; Didier et al. 2013), as suggested by experimental (Teufel and Heinrich 1997; Seydoux-Guillaume et al. 2002; Hetherington et al. 2010; Williams et al. 2011) and petrological studies (Poitrasson et al., 1996, 2000; Mathieu et al., 2001; Gordon et al., 2009; Bosse et al., 2009; Tartèse et al., 2012; Didier et al., 2013), in which it is shown that fluid-assisted dissolutionprecipitation mechanisms are efficient at modifying the chemical and isotopic 
composition of monazite, even at low temperature (down to $\sim 300{ }^{\circ} \mathrm{C}$ ) (Hawkins and Bowring , 1997; Townsend et al., 2000).

\subsection{Late-stage, high-temperature deformation in the FGG}

It is noteworthy that the episode of monazite growth around 295 Ma within the FGG is younger than the age obtained for the neighboring augen gneisses. In the Caroux subdome, monazite U-Th-Pb dating by TIMS of the Pont de Larn orthogneiss (MN 15) and by LA-ICPMS of the Gouffre du Cerisier augen gneiss (MN14-03) yield similar concordia ages of $311.8 \pm 0.5$ and $314.1 \pm 1.3 \mathrm{Ma}$, respectively (Figs. 1, 7; Table 1 ). The same is true for the age obtained on the Gorges d'Héric augen gneiss (MN 7) (308 23 Ma) (Roger et al., 2015) (Figs. 10, 11, 12; Table S5). These are interpreted as the crystallization age of monazite during Variscan metamorphism. In the Gorges d'Héric, the augen gneisses were intruded by a syntectonic, fine-grained meta-aplite dike and cut by undeformed pegmatite. The meta-aplite dike has been dated by zircon and monazite ID-TIMS U-Pb at $309 \pm 3 \mathrm{Ma}$ and $313 \pm 1$, respectively. These ages were interpreted as crystallization of the granite dike (Franke et al., 2011) (Figs. 10, 11; Table S5). The Martys granite in the Nore subdome and the Soulié and Anglés granite bodies in the Caroux subdome are syn-kinematic and were likely emplaced at $314 \pm 2 \mathrm{Ma}, 306$ \pm 1.9 Ma and $305 \pm 1.5 \mathrm{Ma}$, respectively (LA-ICPMS monazite; Trap et al., 2017) (Table S5; Fig. 1, 10, 11, 12). The end of magmatism was marked by several generations of late pegmatitic and undeformed granitic dikes that intruded the gneissic rocks of the MNAZ between 297.2 \pm 5.3 and 292.0 \pm 4.4 Ma (K-Ar muscovite) (Franke et al., 2011).

In the Espinouse subdome, monazite U-Pb dating (ID-TIMS) of the La Planésie orthogneiss (MN 5) yields a metamorphic age of $304.5 \pm 1$ Ma (Figs. 1, 5B; Table 1 ). This 
is similar to the LA-ICPMS U-Th-Pb ages of $303.6 \pm 2$ and $301.2 \pm 2.4$ Ma obtained for monazite in the Vialais deformed granite (Roger et al., 2015) (Fig. 10, 11, 12; Table S5).

At the northern edge of the Espinouse subdome, the LA-ICPMS monazite concordia age of $314.4 \pm 1.6 \mathrm{Ma}$ obtained for the Saint-Eutrope augen gneiss (MN 27) is similar within error to the metamorphic ages of the Caroux orthogneisses (MN 15, MN14-03) (Table 1, Figs. 1, 7, 8C, 10, 11, 12). However, the monazites of the Saint-Eutrope mylonite, which is associated with the Espinouse extensional detachment, recorded a mean ${ }^{208} \mathrm{Th} /{ }^{232} \mathrm{~Pb}$ date of $294.4 \pm 4 \mathrm{Ma}$ (LA-ICPMS), interpreted as the age of deformation along the Espinouse detachment shear zone (Pitra et al., 2012) (Figs. 10, 11, 12; Table S5); this deformation may have been associated with fluid infiltration. This age is similar to the ${ }^{40} \mathrm{Ar} /{ }^{39} \mathrm{Ar}$ age of $297 \pm 3 \mathrm{Ma}$ for muscovite recorded in the metasedimentary rocks along the basal sole thrust of the Paleozoic nappes. This Stephanian age is interpreted as associated with synmetamorphic ductile shearing along the main extensional detachments (Maluski et al., 1991), and is consistent with the new monazite LA-ICPMS age of $298.5 \pm 1.8$ Ma obtained on the Montalet/Piquotalen syntectonic granite (sample MN 28) (Table 1, Figs. 1, 4). This age is also similar to the monazite (294 $\pm 1 \mathrm{Ma})$ and zircon $(294 \pm 3 \mathrm{Ma}$ ) LA-ICPMS ages obtained on the same pluton by Poilvet et al. (2011) (average age $=295 \pm 6$ Ma; $N=3$ ), as well as with TIMS and LA-ICPMS ages for monazites and xenotime from two sites of the late syn-kinematic Vialais granite (average age $=303 \pm 2 \mathrm{Ma} ; \mathrm{N}=3$ ) and for the post-kinematic Ourtigas leucogranite (298 \pm 2 Ma) (Roger et al., 2015) (Table S5, Figs. 10, 11, 12).

Recently, in the Espinouse subdome, Poujol et al. (2017) obtained two age groups of 319-318 Ma and 298-295 Ma on the La Salvetat migmatite and the associated Laouzas anatectic granite using the U-Th-Pb monazite LA-ICPMS method (Table S5; Figs. 10, 11, 12). These authors have interpreted the first event at $\sim 319 \mathrm{Ma}$ as a first stage of 
migmatization and the emplacement of the granite and the second event at $\sim 295 \mathrm{Ma}$ as a probable fluid-induced event, possibly related to a melting event identified through the syn-extensional emplacement of the Montalet/Piquotalen and Vialais leucogranites.

To summarize, the young FGG ages of $\sim 295 \mathrm{Ma}$ are in the same range as the emplacement ages of the Piquotalen (298-294 Ma) and Vialais leucogranites (298 Ma) (Poilvet et al., 2011, Roger et al., 2015, this study), as well as the age of a second melting event at $\sim 298-295$ Ma recorded by monazite (U-Th-Pb, LA-ICPMS) and by the muscovite ${ }^{40} \mathrm{Ar}-{ }^{39} \mathrm{Ar}$ system in the La Salvetat migmatite and the Laouzas granite (Poujol et al., 2017) (Fig. 12). These ages are also synchronous with the deformation along the Espinouse detachment shear zone ( 295 Ma) (Maluski et al., 1991; Pitra et al., 2012), the formation of the Stephanian-to-Permian Graissessac-Lodève basin, and the regional syn-depositional volcanism between $\sim 304-282$ Ma (U-Pb Zircon) evidenced by the repetitive occurrence of volcanic layers (tuffs, tonsteins and cinerites) during the Permian basin infilling (Odin, 1986; Bruguier et al., 2003; Michel et al., 2015; Pfeifer et al., 2016) (Fig. 13).

Our collective work (Roger et al., 2015; Whitney et al., 2015; this study) indicates a common history for the Caroux and Espinouse subdomes consistent with recent data for the rest of the MNAZ (Rabin et al., 2015; Trap et al., 2017, Poujol et al., 2017) (Fig. $10,11,12$; Table S5). The U-Th-Pb monazite ages of the MNAZ from the augen gneisses ( 315- 305 Ma) (this study, Roger et al., 2015), migmatites (318-295 Ma) (Poujol et al., 2017; Trap et al., 2017), syn-kinematic granites (Martys, Soulié, Anglès) (315-305 Ma) (Trap et al., 2017), late kinematic Vialais and Montalet/Piquotalen granites ( $\sim 305-300$ Ma) (Poilvet et al., 2011; Roger et al., 2015; this study), and post-kinematic Ourtigas leucogranite ( $298 \mathrm{Ma}$ ) (Roger et al., 2015) (Figs. 10, 11, 12; Table S5), confirm that the high-temperature deformation and high-temperature / low-pressure metamorphic 
conditions of emplacement and crystallization of anatectic granites at shallow crustal levels occurred from $\sim 315$ to $300 \mathrm{Ma}$, clearly postdating regional contraction and nappe emplacement (> $320 \mathrm{Ma}$ ) (Roger et al., 2015) (Figs. 12,13). These results are in contrast to the 330-320 Ma dates obtained by electron probe microanalysis (EPMA) on monazite by Faure et al. (2010) (Fig. 10, 11; Table S5). Moreover, our previous work has also shown that eclogite-facies metamorphism occurred at 315.3 \pm 1.6 Ma (zircon LA-ICPMS; Whitney et al., 2015), which implies that mafic bodies at $>40 \mathrm{~km}$ depth were eclogitized and incorporated in the ascending felsic material that dominantly comprises the dome. The exhumation history appears to span about 20 million years and was likely episodic, including the late stage exhumation associated with structures developed at the northern margin of the dome and in the FGG units within the dome.

The young FGG ages of 295 Ma in the core of the Caroux subdome (Gorges d'Héric, Fig. 2), with similar ages in the north of the Espinouse subdome (sample MN 4), suggest that the FGG layers are part of a network of structures, both at the margin of the Montagne Noire dome in detachment-like structures and in the core of the Caroux, where strain and fluid flow were likely localized during the late-stage history of the Montagne Noire dome. This late shearing may have been localized in the FGG owing to their heterogeneous composition within an otherwise relatively homogeneous augen gneiss body. We propose that the relatively high-temperature deformation in the core of the Caroux subdome was kinematically linked to (1) the east-directed extension event that exhumed the entire dome, and (2) the strike-slip fault system that bounded the Montagne Noire dome in the north and controlled deposition in the nearby GraissessacLodève basin (Fig. 13).

The geochronological results presented here open new questions that go beyond the scope of this paper, concerning the evolution of the Montagne Noire dome, and possibly 
other migmatite domes in which bounding structures that exhume the dome, such as extensional detachments, become increasingly connected to structures inside the dome, as melt-present deformation gives way to solid-state deformation. Results from this study also provide an opportunity for further investigation of the monazite $\mathrm{U}-\mathrm{Th}-\mathrm{Pb}$ geochronologic system, including the role of grain-scale deformation as strain becomes gradually localized during cooling of the dome. Finally, by demonstrating the coeval nature of shear zones around and inside the Montagne Noire dome, the results presented here set the stage for a detailed comparison of microstructures and microfabrics in the FGG and other dome rocks that inform the mechanisms of strain localization in the final stages of dome development.

\section{Acknowledgments}

This research was supported by NSF grant EAR-1050020 to Teyssier and Whitney, including funds from NSF International Programs that helped facilitate international collaboration with scientists at the University of Montpellier. We thank Cyprien Astoury for mineral separation, Jennifer Wright and Roxanne Renedo (University of Minnesota) for early investigation of the FGG, Olivier Raynal for his accurate map and cross section of the Gorges d'Héric, and Maurice Brunel, Philippe Matte, Renaud Caby, André Leyreloup, Mickael Rabin, Pierre Trap, and Bénédicte Cenki-Tok for field trips and discussions in the Montagne Noire. We also thank Philippe Agard, Romain Tartèse, and an anonymous reviewer who helped improve the manuscript.

All the data used in this study are available in the main text and in the supporting information of this manuscript. 


\section{References}

Aerden, D.G.A.M., 1998. Tectonic evolution of the Montagne Noire and a possible orogenic model for syncollisional exhumation of deep rocks, Variscan belt, France. Tectonics, 17, 62-79.

Aerden, D.G.A.M., Malavieille, J.,1999. Origin of a large-scale fold nappe in the Montagne Noire, Variscan belt, France. Journal of Structural Geology, 21, 1321-1333.

Alexandre, P., 2007. U-Pb zircon SIMS ages from the French Massif Central and implication for the pre-Variscan tectonic evolution in Western Europe. C R Geosci $339,613-621$.

Arthaud, F., 1970. Etude tectonique et microtectonique comparée de deux domaines hercyniens: les nappes de la Montagne Noire (France) et l'anticlinorium de l'Iglesiente (Sardaigne). Université des Sciences et Techniques du Languedoc, p. 175.

Bard, J.P., Rambeloson, R., 1973. Métamorphisme plurifacial et sens de variation du degrès géothermique durant la tectogenèse polyphasée hercynienne dans la partie orientale de la zone axiale de la Montagne Noire (massif du Caroux, sud du Massif Central français). Bull. Soc. Geol. Fr. 15, 579-586.

Bé Mezème, E., Cocherie, A., Faure, M., Legendre, O., Rossi, P., 2006. Electron microprobe monazite geochronology: a tool for evaluating magmatic age domains. Examples from the Variscan French Massif Central. Lithos 87, 276-288.

Beaud, F., 1985. Etude structurale de la Zone Axiale orientale de la Montagne Noire (Sud du Massif Central Français). Détermination des mécanismes de déformation. Relation avec les nappes du Versant Sud: Thèse 3ème cycle. Université des Sciences et Techniques du Languedoc, Montpellier (191 pp.). 
Bosse, V., Boulvais, P., Gautier, P., Tiepolo, M., Ruffet, G., Devidal, J.L., Cherneva, Z., Gerdjikov, I., Paquette, J.L., 2009. Fluid induced disturbance of the monazite $\mathrm{Th}-\mathrm{Pb}$ chronometer: In situ dating and element mapping in pegmatites from the Rhodope (Greece, Bulgaria). Chem Geol 261, 286-302.

Bogdanoff, S., 1970. Contribution à l'étude géologique de l'extrémité orientale de la zone axiale granite-gneissique de la Montagne Noire, Thèse $3^{\circ}$ cycle. Univ. Orsay (91 pp.).

Bogdanoff, S., Donnot, M. and Ellenberger, F., 1984. Carte géologique de Bédarieux. Carte géologique de la France au 1/50000, no. 988.

Bruguier, O., Becq-Giraudon, J.F., Champenois, M., Deloule, E., Ludden, J., Mangin, D., 2003. Application of in situ zircon geochronology and accessory phase chemistry to constraining basin development during post-collisional extension: a case study from the French Massif Central. Chem. Geol. 201, 319-336.

Brun, J.P., Van Den Driessche, J., 1994. Extensional gneiss domes and detachment fault systems: structure and kinematics. Bull. Soc. Geol. Fr. 165 (6), 519-530.

Brun, J.P., Van Den Driessche, J., 1996. Réponse à observations et remarques sur l'article "Extensional gneiss domes and detachment fault systems/structure and kinematics (Brun, J.P., Van Den Driessche, J., 1994, Bull. Soc. Géol. Fr. 165 (6), 519-530)”. Bull. Soc. Geol. Fr. 167 (2), 295-302.

Brunel, M., Lansigu, C., 1997. Deformation and kinematics of emplacement of the axial dome of the Montagne Noire: implications of quartz-sillimanite nodule attitudes (French Massif Central). C. R. Acad. Sci. Paris II 325 (7), 517-523.

Chelle-Michou, C., Laurent, O., Moyen, J.-F., Block, S., Paquette, J.-L., Couzinié, S., Gardien, V., Vanderhaeghe, O., Villaros, A., Zeh, A., 2017. Pre-Cadomian to late-Variscan odyssey of the eastern Massif Central, France: formation of the West European crust in a nutshell. Gondwana Research 46, 170-190. 
Cherniak, D.J., Watson, B.E., Grove, M., Harrison, T.M., 2004. Pb diffusion in monazite: a combined RBS/SIMS study. Geochim Cosmochim Acta 68, 829-840.

Cocherie, A., Baudin, T., Autran, A., Guerrot, C., Fanning, M., Laumonier, B., 2005. U-Pb zircon (ID-TIMS and SHRIMP) evidence for the early Ordovician intrusion of metagranites in the late Proterozoic Canaveilles Group of the Pyrenees and the Montagne Noire (France). Bull. Soc. Geol. Fr. 176, 269-282.

Coney, P.J., Harms, T.A., 1984. Cordilleran metamorphic core complexes: Cenozoic extensional relics of Mesozoic compression. Geology, v. 12, p. 550-554.

Demange, M., 1982. Etude géologique du Massif de l'Agoût, Montagne Noire, France. A geologic study of the Agoût Massif, Montagne Noire, France, Doctoral, Univ. Paris VI.

Demange, M., 1985. The eclogite-facies rocks of the Montagne Noire, France. Chem. Geol. $50,173-188$

Demange, M., 1999. Evolution tectonique de la Montagne Noire: un modèle en transpression. C. R. Acad. Sci. Paris 329, 823-829.

Demange, M., Guérangé-Lozes, J., Guérangé, B., 1996. Carte géologique de Lacaune et sa notice. Carte géologique de la France au 1:50000 nº87, Bureau de Recherches Géologiques et Minières, Orléans, France.

Den Tex, E., 1975. Thermally mantled gneiss domes; the case for convective heat flow in more or less solid orogenic basement. In: Borradaile, G.J., Ritsema, A.R., Rondeel, H.E. and Simon, O.J. (Eds.), Geodynamics Project, Scientific Report. North-Holland Publ. Co., Amsterdam, Netherlands.

Didier, A., Bosse, V., Cherneva, P., Gautier, P., Georgieva, M., Paquette, J.L., Gerdjiko, I., 2014. Syn-deformation fluid-assisted growth of monazite during renewed high-grade metamorphism in metapelites of the Central Rhodope (Bulgaria, Greece). Chemical Geology, 381, 206-222. 
Didier, A., Bosse, V., Boulvais, P., Bouloton, J., Paquette, J.L., Montel, J.M., Devidal, J.L., 2013. Disturbance versus preservation of $\mathrm{U}-\mathrm{Th}-\mathrm{Pb}$ ages in monazite during fluidrock interaction: textural, chemical and isotopic in situ study in microgranites (Velay Dome, France). Contrib. Miner. Petrol. 165, 1051-1072.

Ducrot, J., Lancelot, J.R., Reille, J.L., 1979. Datation en Montagne Noire d'un témoin d'une phase majeure d'amincissement crustal caractéristique de l'Europe prévarisque. Age of a major phase of crustal thinning characteristic of Prevariscan Europe determined in the Montagne Noire region. Bull. Soc. Geol. Fr. 21 (4), 501-505.

Echtler, H., Malavieille, J., 1990. Extensional tectonics, basement uplift and StephanoPermian collapse basin in a late Variscan metamorphic core complex (Montagne Noire, southern Massif Central). Tectonophysics 177, 125-138.

Faure, M., Cottereau, N., 1988. Données cinématiques sur la mise en place du dôme migmatitique carbonifère moyen de la zone axiale de la Montagne Noire (Massif Central, France). C. R. Acad. Sci. Paris 307, 1787-1794.

Faure, M., Cocherie, A., Bé Mézène, E., Charles, N., Rossi, P., 2010. Middle Carboniferous crustal melting in the Variscan belt: new insights from U-Th-Pbtot monazite and U$\mathrm{Pb}$ zircon ages of the Montagne Noire Axial Zone (southern French Massif Central). Gondwana Res. 18, 653-673.

Faure, M., Cocherie, A., Gaché, J., Esnault, C., Guerrot, C., Rossi, Ph., Wei, Lin, Qiuli, Li, 2014. Middle Carboniferous intracontinental subduction in the outer zone of the Variscan belt (Montagne Noire Axial Zone, French Massif Central): multimethod geochronological approach of polyphase metamorphism. Geol. Soc. Lond. Spec. Publ. https://doi.org/10.1144/SP405.2. 
Finger, F., Krenn, E., 2007. Three metamorphic monazite generations in a high-pressure rock from the Bohemian Massif and the potentially important role of apatite in stimulating polyphase monazite growth along a PT loop. Lithos 95: 103-115.

Franke, W., Doublier, M.P., Klama, K., Potel, S., Wemmer, K., 2011. Hot metamorphic core complex in a cold foreland. Int. J. Earth Sci. (Geol. Rundsch.), https://doi.org/10.1007/s00531-010-0512-7.

Fréville, K., Cenki-Tok, B., Trap, P., Rabin, M., Leyreloup, A., Régnier, J.L., Whitney, D., 2016. Thermal interaction of middle and upper crust during gneiss dome formation: example from the Montagne Noire (French Massif Central). J Metamorph Geol 34:447-462. https:// doi:10.1111/jmg.12188

Gardés, E., Montel, J.M., Seydoux-Guillaume, A.M., Wirth, R., 2007. Pb diffusion in monazite: New constraints from the experimental study of $\mathrm{Pb}^{2+} \leftrightarrow \mathrm{Ca}^{2+}$ interdiffusion. Geochim. Cosmochim. Acta 71, 4036-4043.

Gebauer, D., Compston, W., Williams, I.S., Grünenfelder, M., 1988. U-Pb zircon ion-probe dating of augen gneisses of the Montagne Noire and the significance of the Caledonian subcycle in the French Massif Central. In: Terranes in the Variscan belt of France and western Europe, Abstract Volume.

Gèze, B., 1949. Etude géologique de la Montagne Noire et des Cévennes méridionales. Soc. Géol. Fr. Mém. 62, 1-125.

Gordon, S.M., Grove, M., Whitney, D.L., Schmitt, A.K., Teyssier, C., 2009. Timetemperature-fluid evolution of migmatite dome crystallization: Coupled $\mathrm{U}-\mathrm{Pb}$ age, $\mathrm{Ti}$ thermometry, and 0 isotopic ion microprobe depth profiling of zircon and monazite. Chemical Geology, 262, 186-201. 
Hawkins, D., Bowring, S., 1997. U-Pb systematics of monazite and xenotime: case studies from the Paleoproterozoïc of the Grand Canyon, Arizona. Contrib. Miner. Petr. 127, 87-103.

Hetherington, C.J., Harlov D.E., Budzyn, B., 2010. Experimental metasomatism of monazite and xenotime: mineral stability, REE mobility and fluid composition. Contrib. Mineral. Petrol. 99, 165-184.

Hurai, V., Paquette, J.L., Huraiovà, M., Konecny, P., 2010. U-Th-Pb geochronology of zircon and monazite from syenite and pincinite xenoliths in Pliocene alkali basalts of the intra-carpathian back-arc basin. J. Volcanol. Geotherm. Res. 198, 275-287.

Jaffey, A.H., Flynn, K.F., Glendenin, L.E., Bentley, W.C., Essling, A.M., 1971. Precision measurement of half-lives and specific activities of ${ }^{235} \mathrm{U}$ and ${ }^{238} \mathrm{U}$. Phys. Rev. C4, 1889-1906.

Jolivet, L., Famin, V., Mehl, C., Parra, T., Aubourg, C., Hébert, R., and Philippot, P., 2004, Strain localization during crustal-scale boudinage to form extensional metamorphic domes in the Aegean Sea, in Whitney, D.L., et al., eds., Gneiss domes in orogeny: Geological Society of America Special Paper 380, p. 185-210.

Kelly, N.M., Harley, S.L., Möller, A., 2012. Complexity in the behavior and recrystallization of monazite during high-T metamorphism and fluid infiltration. Chem. Geol. 322-323:192-208.

Korchinski, M., Rey, P.F., Mondy, L., Teyssier, C., Whitney, D.L., 2018. Numerical investigation of deep-crust behavior under lithospheric extension. Tectonophysics $726,137-146$.

Kruckenberg, S.C., Vanderhaeghe, O., Ferré, E.C., Teyssier, C., Whitney, D.L., 2011. Flow of partially molten crust and the internal dynamics of a migmatite dome: Naxos, Greece. Tectonics. https:// doi.org/10.1029/2010TC002751. 
Lister, G.S., Banga, G., Feenstra, A., 1984. Metamorphic core complexes of Cordilleran type in the Cyclades Aegean Sea, Greece. Geology, v. 12, p. 221-225.

Loueyit, C.J., 1978. Etude pétrographique des Monts de l'Espinouse dans la zone axiale de la Montagne Noire (Massif Central français). Mém. DEA, Univ. Sciences et Techniques du Languedoc (57 pp.).

Ludwig, K.R., 1993. Pbdat: a computer program for processing $\mathrm{Pb}-\mathrm{U}-\mathrm{Th}$ isotope data, version 1.24. United States Geological Survey Open-file Report pp. 88-542.

Ludwig, K.R., 2001. User manual for Isoplot/Ex rev. 2.49. A geochronological toolkit for Microsoft Excel. Berkeley Geochronology Center Special Publication 1a, pp. 1-56.

Malavieille, J., Konstantinoskaya, E., 2010. Impact of surface processes on the growth of orogenic wedges: insights from analog models and case studies. Geotectonics 44(6), 541-558.

Malavieille, J., 2010. Impact of erosion, sedimentation and structural heritage on the structure and kinematics of orogenic wedges: analog models and case studies. GSA Today, 20, 4-10.

Maluski, H., Costa, S., Echtler, H., 1991. Late Variscan tectonic evolution by thinning of earlier thickened crust: an 40Ar-39Ar study of the Montagne Noire, southern Massif Central, France. Lithos 26 (3-4), 287-304.

Mathieu, R., Zetterström, L., Cuney, M., Gauthier-Lafaye, F., Hidaka, H., 2001. Alteration of monazite and zircon and lead migration as geochemical tracers of fluid paleocirculations around the Oklo-Okélobondo and Bamgombé natural nuclear reaction zones (Franceville basin, Gabon). Chem. Geol. 171,147-171.

Mattauer, M., Laurent, Ph., Matte, Ph., 1996. Plissement hercynien syn-schisteux postnappe et étirement subhorizontal dans le versant sud de la Montagne Noire (Sud du Massif Central, France). Post-nappe syn-schistose Hercynian folding and horizontal 
stretching in the southern side of Montagne Noire, southern Central Massif, France. C.R. Acad. Sci. II 322 (4), 309-315.

Mattauer, M., 2004. Orthogneisses in the deepest levels of the Variscan belt are not a Precambrian basement but Ordovician granites: tectonics consequences. C.R. Geosciences 336, 487-489.

Matte, Ph., 2007. Variscan thrust nappes detachments and strike-slip faults in the French Massif Central: interpretation of the lineations. Geol. Soc. Am. Mem. 200, 319402.

Matte, Ph., Lancelot, J., Mattauer, M., 1998. La Zone axiale hercynienne de la Montagne Noire n'est pas un "metamorphic core complex" extensif mais un anticlinal postnappe à coeur anatectique. Geodin. Acta (Paris) 11 (1), 13-22.

Melleton, J., Cocherie, A., Faure, M., Rossi, P., 2010. Precambrian protoliths and Early Paleozoic magmatism in the French Massif Central: U-Pb data and the North Gondwana connection in the west European Variscan belt. Gondwana Research 17, $13-25$.

Michel, L.A., Tabor, N.J., Montanez, I.P., Schmitz, M.D., Davydov, V.I., 2015. Chronostratigraphy and paleoclimatology of the Lodeve Basin, France: evidence for a pan-tropical aridification event across the Carboniferous-Permian boundary. Palaeogeogr. Palaeoclimatol. Palaeoecol. 430, 118-131.

Nicolas, A., Bouchez, J.L., Blaise, J.L., Poirier, J.P., 1977. Geological aspects of deformation in continental shear zones. Tectonophysics $42,55-73$.

Odin, B., 1986. Les formations permiennes, Autunien supérieur à Thuringienne, du Bassin de Lodève. Thèse, Université Aix-Marseille III: 392pp.

Paquette, J.L., Pin, C., 2001. A new miniaturized extraction chromatography method for precise U-Pb zircon geochronology. Chem. Geol. 176 (1-4), 311-319. 
Paquette, J.L., Piro, J.L., Devidal, J.L., Bosse, V., Didier, A., 2014. Sensitivity enhancement in LA-ICP-MS by N2 addition to carrier gas: application to radiometric dating of U-Thbearing minerals. Agilent ICP-MS journal, 58, 4-5.

Pfeifer, L.S., Soreghan, G.S., Pochat, S., Van Den Driessche, J., Thomson, S.N., 2016. Rapid Permian exhumation of the Montagne Noire metamorphic core complex recorded in provenance of upper Paleozoic clastic strata in the Graissessac-Lodève Basin, France. Basin Research. https:// doi: 10.1111/bre.12197.

Pitra, P., Poujol, M., Van Den Driessche, J., Poilvet, J.C., Paquette, J.L., 2012. Early Permian extensional shearing of an Ordovician granite: the Saint-Eutrope "C/S-like" orthogneiss (Montagne Noire, French Massif Central). C. R. Geosci. https://doi.org/10.1016/j.crte.2012.06.002.

Poilvet, J.C., Poujol, M., Pitra, P., Van Den Driesssche, J., Paquette, J.L., 2011. The Montalet granite, Montagne Noire, France: an Early Permian syn-extensional pluton as evidenced by new U-Th-Pb data on zircon and monazite. C. R. Geosci. 343, 454-461. https:// doi.org/10.1016/j.crte.2011.06.002.

Poitrasson, F., Chenery, S., Bland, D.J., 1996. Contrasted monazite hydrothermal alteration mechanisms and their geochemical implications. Earth Planet. Sci. Lett. $145,79-96$.

Poitrasson, F., Chenery, S., Shepherd, T.J., 2000. Electron microprobe and LA-ICP-MS study of monazite hydrothermal alteration: implications for $\mathrm{U}-\mathrm{Th}-\mathrm{Pb}$ geochronology and nuclear ceramics. Geochim. Cosmochim. Acta 64, 3283-3297.

Poujol, M., Pitra, P., Van Den Driessche, J., Tartèse, R., Ruffet, G., Paquette, J.L., Poilvet, J.C., 2017. Two-stage partial melting during the Variscan extensional tectonics (Montagne Noire, France). Int. J. Earth Sci.. https://doi: 10.1007/s00531-016-1369-1. 
Pyle, J., Spear, F., 2003. Four generations of accessory-phase growth in low-pressure migmatites from SW New Hampshire. Am. Mineral. 88, 338-351.

Rabin, M., Trap, P., Carry, N., Fréville, K., Centi-Tok, B., Lobjoie, C., Goncalves, P., Marquer, D., 2015. Strain partitioning along the anatectic front in the Variscan Montagne Noire massif (southern French Massif Central). Tectonics. https://doi:10.1002/2014TC003790.

Raynal, 0., 2004. Etude des boudins amphibolitiques, péridotiques et éclogitiques dans leur position structurale le long de la coupe des Gorges d'Héric. Unpublished report, pp. 33, Université Montpellier 2.

Rey, P.F., Teyssier, C., Wittney, D.L., 2009a. The role of partial melting and extensional strain rates in the development of metamorphic core complexes. Tectonophysics $477,133-144$.

Rey, P., Teyssier, C., Whitney, D.L., 2009b. Crustal melting and core complex dynamics. Geology 37 (5), 391-394.

Rey, P.F., Teyssier, C., Kruckenberg, S.C., Whitney, D.L., 2011. Viscous collision in channel explains double domes in metamorphic core complexes. Geology 39(4), 387-390.

Rey, P.F., Teyssier, C., Kruckenberg, S.C., Whitney, D.L., 2012. Viscous collision in channel explains double domes in metamorphic core complexes. Geology, Forum Reply, October, 2012, https://doi. 1130/G33202Y.1.

Rey, P.F., Mondy, L., Duclaux, G., Teyssier, C., Whitney, D.L., Bocher, M., Prigent, C., 2017. The origin of contractional structures in extensional gneiss domes. Geology 45 (3), 263-266. https://dx.doi.org/10.1130/G38595.1.

Roger, F., Respaut, J.P., Brunel, M., Matte, Ph., Paquette, J.L., 2004. Première datation U$\mathrm{Pb}$ des orthogneiss oeillés de la zone axiale de la Montagne Noire (Sud du Massif 
Central): nouveaux témoins du magmatisme ordovicien dans la chaîne varisque. C. R. Geosci. Acad. Sci. Paris 336, 19-28.

Roger, F., Teyssier, C., Respaut, J.P., Rey, P., Jolivet, M., Whitney, D.L., Paquette, J.P., Brunel, M., 2015. Timing of deformation and exhumation of the Montagne Noire double dome, French Massif Central, Tectonophysics, 640-641, 53-69.

Schuiling, R.D., 1960. Le dome gneissique de l'Agoût (Tarn et Hérault). Mémoires de la Sociéte Géologique de France. Nouv. Ser. 39 (91), 59.

Schuiling, R.D., Widt, J., 1962. Sur la génèse du dôme gneissique de l'Agoût (Dépts Tarn et Hérault). Geol. Mijnb. Ned. 41, 321-326.

Seydoux-Guillaume, A.M., Paquette, J.L., Wiedenbeck, M., Montel, J.M., Heinrich, W., 2002. Experimental resetting of the U-Th-Pb systems in monazite. Chem. Geol. 191, 165181.

Soula, J.C., Debat, P., Brusset, S., Bessiere, G., Christophoul, F., Deramond, J., 2001. Thrustrelated, diapiric, and extensional doming in a frontal orogenic wedge: example of the Montagne Noire, southern French Hercynian Belt. J. Struct. Geol. 23 (11), 16771699.

Stacey, J.S., Kramers, J.D., 1975. Approximation of terrestrial lead isotope evolution by a two-stage model. Earth Planet. Sci. Lett. 26, 207-221. Steiger, R.H., Jäger, E., 1977. Subcommission on geochronology: convention on the use of decay constants in geoand cosmochronology. Earth Planet. Sci. Lett. 36, 359-362.

Steiger, R.H., Jäger, E., 1977. Subcommission on geochronology: convention on the use of decay constants in geo- and cosmochronology. Earth Planet. Sci. Lett. 36, 359-362.

Tartèse, R., Boulvais, P., Poujol, M., Chevalier, T., Paquette, J.L., Ireland, T.R., Deloule, E., 2012. Mylonites of the South Armorican Shear Zone: insights for crustal-scale fluid flow and water-rock interaction processes. J. Geodyn. 56-57, 86-107. 
Teufel, S., Heinrich, W., 1997. Partial resetting of the U-Pb isotope system in monazite through hydrothermal experiments: an SEM and U-Pb isotope study. Chem Geol 137, $273-281$.

Townsend, K.J., Miller, C.F., D'Andrea, J.L., Ayers, J.C., Harrison, T.M., Coath, C.D., 2000. Low temperature replacement of monazite in the Ireteba granite, Southern Nevada: geochronological implications. Chem Geol 172, 95-112.

Thompson, P.H., Bard, J.P., 1982. Isograds and mineral assemblages in the Eastern Axial Zone, Montagne Noire (France): implications for temperature gradients and $\mathrm{P} / \mathrm{T}$ history. Can. J. Earth Sci. 19 (1), 129-143.

Teipel, U., Eichhorn, R., Loth, G., Rohrmüller, J., Höll, R., Kennedy, A., 2004. U-Pb SHRIMP and $\mathrm{Nd}$ isotopic data from the western Bohemian Massif (Bayerischer Wald, Germany): implications for Upper Vendian and Lower Ordovician magmatism. International Journal of Earth Sciences 93, 782-801.

Trap, P., Roger, F., Cenki-Tok, B. and Paquette, J.L., 2017. Timing and duration of partial melting and magmatism in the Variscan Montagne Noire gneiss done (French Massif Central). Int. J. Earth Sci. 106, 453-476. https://doi 10.1007/s00531-016-1417-x.

van Achterbergh, E., Ryan, C., Jackson, S., Griffin, W., 2001. Data reduction software for LA-ICP-MS. In: Sylvester, P. (Ed.), Laser Ablation-ICPMS in the Earth Science. Mineralogical Association of Canada, pp. 239-243.

Van Den Driessche, J., Brun, J.P., 1989. Kinematic model of late Paleozoic extensional tectonics in the southern French Massif Central. C. R. Acad. Sci. II 309 (16), 16071613.

Van Den Driessche, J., Brun, J.P., 1992. Tectonic evolution of the Montagne Noire (French Massif Central): a model of extensional gneiss dome. Geodin. Acta 5, 85-99. 
Van Den Driessche, J., Pitra, P., 2012. Viscous collision in channel explains double domes in metamorphic core complexes, Forum Comment, Geology 40 (10), E279. https://doi.org/10.1130/G32727C.1.

Whitney, D.L., Teyssier, C., Rey, P., Buck, W.R., 2013. Continental and oceanic core

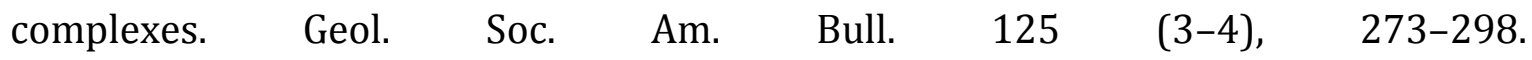
https://doi.org/10.1130/B30754.1.

Whitney, D.L., Roger, F., Teyssier, C., Rey, P.F., J.P. Respaut, 2015. Syn-collapse eclogite metamorphism and exhumation of deep crust in a migmatite dome: the P-T-t record of the youngest Variscan eclogite (Montagne Noire, French Massif Central). Earth and Planetary Science Letters, 430, 224-234. https://doi: 10.1016/j.epsl.2015.08.026.

Williams, M.L., Jercinovic, M., Harlov, D.E., Budzyn. B., Hetherington. C.J., 2011. Resetting monazite ages during fluid-related alteration. Chem Geol 283, 218-225. 


\section{FIGURE CAPTIONS}

Fig. 1: (A) Map of some of the Variscan massifs in western Europe: Armorican (ARM), Iberian (IB), Massif Central (MC), and Pyrenees (PYR). The rectangle at the southern end of the Massif Central shows the location of the Montagne Noire. (B) Simplified geological sketch map of the Montagne Noire (foliation trajectories after Rabin et al., 2015, and Roger et al., 2015, for the eastern end of the dome) with geochronological results and sample locations. Variscan granites are shown in red color.

Fig. 2: (A) Structural map of the Gorges d'Héric area, modified from Raynal (2004), with geochronological results and sample locations. (B) South-North trending cross section of the Caroux subdome with projected locations of dated samples (augen gneiss and fine-grained gneisses). FGG units encountered along the Héric stream, as well as sample localities, are projected on the topographic cross section (X-Y dashed line).

Fig. 3: (A) Outcrop of MN11-47 FGG composed of alternating bands of strongly foliated fine grained biotite gneiss and highly sheared leucosome layers; (B) BSE image of a swath of a thin section of MN11-47B showing the fine grain size, including small garnets, of the leucosome; a more biotite-rich layer is present near the top of the section; (C) Photomicrograph of biotite-plagioclase-rich FGG (MN11-59) showing sigmoidal foliation (top-to-E shear sense); (D) and (E): Scanning electron microscope (SEM) images of thin sections showing the textural position of monazite grains within FGG samples MN11-47B and MN11-119 from Gouffre du Cerisier. The white and red 
circles indicate spot analyses with a diameter of $26 \mu \mathrm{m}$ for zircon and $7 \mu \mathrm{m}$ for monazite, and adjacent numbers correspond to ${ }^{206} \mathrm{~Pb} /{ }^{238} \mathrm{U}$ dates and ${ }^{208} \mathrm{~Pb} /{ }^{232} \mathrm{Th}$ dates obtained on zircon and monazite, respectively. $\mathrm{Z}$ and Mo number correspond to the zircon and monazite grain numbers reported in Table S3 and S4.

Fig. 4: Monazite LA-ICPMS U-Th-Pb concordia diagrams obtained on the sheared Piquotalen granite (MN 28), Espinouse sub-dome. Error ellipses and uncertainties on ages are $\pm 2 \sigma$.

Fig. 5: Monazite U-Pb concordia diagrams obtained on gneiss of the Espinouse subdome by TIMS or LA-ICPMS. Error ellipses and uncertainties on ages are $\pm 2 \sigma$.

Saint-Eutrope augen gneiss by LA-ICPMS (MN 27); (B) La Planésie augen gneiss by TIMS (MN 5) and (C) Candoubre FGG (MN 4).

Fig. 6: Zircon U-Pb concordia diagrams obtained on Candoubre FGG (MN 4), Espinouse sub-dome, by LA-ICPMS. Error ellipses and uncertainties in ages are $\pm 2 \sigma$. The numbers refer to analytical data in Table S4. Grey-filled ellipses are discordant data and are not taken into account in the ${ }^{206} \mathrm{~Pb} /{ }^{238} \mathrm{U}$ dates histogram. The binned frequency plot shows the presence of three major populations (black histogram boxes) yielding concordia ages at $290 \pm 9 \mathrm{Ma}, 579 \pm 12 \mathrm{Ma}$ and $644 \pm 7 \mathrm{Ma}$. 
Fig. 7: Monazite U-Th-Pb concordia diagrams obtained on the augen gneiss of the Caroux sub-dome. (A) Pont de Larn augen gneiss by TIMS (MN 15), and (B) Gouffre du Cerisier augen gneiss by LA-ICPMS (MN 14-03). Error ellipses and uncertainties in ages are $\pm 2 \sigma$. The white ellipses are not taken into account for the age calculation.

Fig. 8: Monazite U-Th-Pb concordia diagrams obtained on the FGG by TIMS or LAICPMS. (A) Héric FGG (MN11-59), Caroux sub-dome, (B) Roc du Caroux FGG (MN1157). (C) Roc de Peyris FGG (MN11-27). Error ellipses and uncertainties in ages are $\pm 2 \sigma$. The white ellipses are not taken into account for the age calculation.

Fig. 9: Monazite U-Th-Pb concordia diagrams obtained on the Gouffre du Cerisier FGG, Gorges d'Héric, by LA-ICPMS. (A) Sample MN11-121. (B) Sample MN11-118. (C) Sample MN11-117. (D, E and F) Sample MN11-47. (G) Sample MN11-119A. The concordia diagram of this sample shows the presence of two populations: one at $297.3 \pm 1.6 \mathrm{Ma}$ (grey ellipses) and second at $316.9 \pm 5.5 \mathrm{Ma}$ (white ellipse). No correlation is observed between the textural position of these populations (e.g., inclusion vs. matrix) and the ages. In the Concordia diagrams $\mathrm{C}, \mathrm{D}, \mathrm{E}$ and $\mathrm{F}$, the white ellipses are not taken into account for the age calculation. Error ellipses and uncertainties in ages are $\pm 2 \sigma$.

Fig. 10: Synthesis of Variscan ages obtained by the U-Th-Pb method in the Montagne Noire Axial Zone. Ages are $\pm 2 \sigma$. (1) this study; (2) Our previous results (Roger et al., 2015 and Whitney et al., 2015); (3) Trap et al. (2017) ; (4) Poilvet et al. (2011), Pitra et 
al. (2012) and Poujol et al. (2017); (5) Franke et al. (2011) ; (6) Faure et al. (2010) and Faure et al. (2014); and (7) Matte et al. (1998). The number corresponds to an age reported in Table S5. See text and Table S5 for detail.

Fig. 11: Synthetic map of the U-Th-Pb ages for the Axial Zone of the Montagne Noire (see text for detail, as well as Fig. 10 and Table S5).

Fig. 12: Histograms of the U-Th-Pb Variscan ages recorded on the plutonic $(A)$ and metamorphic (B) rocks from the Axial Zone of the Montagne Noire. The data are reported in Table S5. All monazite EPMA (\# 40, 41,43, 44, 45, 47, 48, 49) and two zircon U-Pb (\#46, 55) dates obtained by Faure et al. (2010) and Matte et al. (1998) are not taken into account because they are significantly older ( 320-335 Ma) than the other data set ( $\sim 290-315 \mathrm{Ma}$ ) (see text for detail, as well as Fig. 10 and Table S5). These older date are probably meaningless artefacts like that was proposed in the recent geochronological studies (see more detail in Roger et al. (2015), Trap et al. (2017) and Poujol et al. (2017)). The yellow circles below each diagram denote the individual data used to generate the diagrams.

Fig. 13: (A) Schematic block diagram of the eastern end of the Montagne Noire Espinouse and Caroux sub-domes showing localized deformation in the FGG units at $\sim 295 \mathrm{Ma}$ in relation to coeval events, such as extensional structures in overlying units, shearing along the dome northern region, intrusion of the Montalet granite, and 
deformation of the Stephanian Graissessac basin. Also portrayed are Variscan metamorphic ages of rare eclogite (zircon U-Pb ages) and abundant augen gneiss (monazite ages) from the MNAZ (315-300 Ma). (Z): Zircon U-Th-Pb age; (Mz): Monazite $\mathrm{U}-\mathrm{Th}-\mathrm{Pb}$ age; (Xe): Xenotime U-Th-Pb age; (Bt): Biotite ${ }^{40} \mathrm{Ar}-{ }^{39} \mathrm{Ar}$ age and (Mus) Muscovite ${ }^{40} \mathrm{Ar}-{ }^{39} \mathrm{Ar}$ age (see text for detail, as well as Figs. 10 and Table S5). (B) Schematic block diagrams of the evolution of the Montagne Noire dome with snapshots at >315 Ma, $310 \mathrm{Ma}$, and $295 \mathrm{Ma}$.

Table 1: Summary of geographic location, rock types, and U-Th-Pb geochronological results for samples analyzed in this study. Most analyses on separated monazite, except when specified: *: monazite age obtained on thin section; (Z): zircon age; italic text : old monazite preserved (see detail in the text).

\begin{tabular}{|c|c|c|c|c|c|}
\hline & $\begin{array}{l}\text { Location } \\
\text { and }\end{array}$ & & \multicolumn{2}{|c|}{ U-Th- $\mathrm{Pb}$ age } & \\
\hline Sample & Rock type & $\begin{array}{l}\text { GPS } \\
\text { Location }\end{array}$ & TIMS & $\begin{array}{l}\text { LA- } \\
\text { IS }\end{array}$ & Comment \\
\hline \multicolumn{6}{|c|}{ CAROUX SUBDOME } \\
\hline MN 15 & $\begin{array}{l}\text { Pont de } \\
\text { Larn } \\
\text { Augen } \\
\text { Gneiss }\end{array}$ & $\begin{array}{l}\mathrm{N} \\
43^{\circ} 29^{\prime} 38^{\prime \prime} \\
\mathrm{E} \\
2^{\circ} 26^{\prime} 06^{\prime \prime}\end{array}$ & $\begin{array}{l}311.8 \pm \\
0.5 \mathrm{Ma}\end{array}$ & & Concordia \\
\hline MN14-03 & $\begin{array}{l}\text { Gouffre } \\
\mathrm{du} \\
\text { Cerisier } \\
\text { Augen } \\
\text { Gneiss }\end{array}$ & $\begin{array}{l}\mathrm{N} \\
099^{\prime} \\
\mathrm{E} \\
2^{\circ} 57^{\prime} 30^{\prime},\end{array}$ & & $314.1 \pm$ & Concordia \\
\hline MN11-27 & $\begin{array}{l}\text { Roc du } \\
\text { Peyris } \\
\text { Fine } \\
\text { Grained } \\
\text { Gneiss }\end{array}$ & $\begin{array}{l}\mathrm{N} \\
43^{\circ} 35^{\prime} 02^{\prime \prime} \\
\mathrm{E} \\
2^{\circ} 57^{\prime} 41^{\prime \prime}\end{array}$ & & $\begin{array}{l}294.6 \pm \\
\text { Ia }\end{array}$ & Concordia \\
\hline MN11-121 & $\begin{array}{l}\text { Gouffre } \\
\mathrm{du} \\
\text { Cerisier } \\
\text { Fine } \\
\text { Grained }\end{array}$ & $\begin{array}{l}\mathrm{N} \\
43^{\circ} 35^{\prime} 02^{\prime \prime} \\
\mathrm{E} \\
2^{\circ} 57^{\prime} 41^{\prime \prime}\end{array}$ & & $\begin{array}{l}294.9 \pm \\
\text { Ia }\end{array}$ & \begin{tabular}{|l} 
Mean \\
${ }^{232}$ Th age
\end{tabular} \\
\hline
\end{tabular}




\begin{tabular}{|c|c|c|c|c|c|}
\hline & Gneiss & & & & \\
\hline MN11-47 & $\begin{array}{l}\text { Gouffre } \\
\text { du } \\
\text { Cerisier } \\
\text { Fine } \\
\text { Grained } \\
\text { Gneiss }\end{array}$ & $\begin{array}{l}\mathrm{N} \\
43^{\circ} 35^{\prime} 11^{\prime \prime} \\
\mathrm{E} \\
2^{\circ} 57^{\prime} 34^{\prime \prime}\end{array}$ & & $\begin{array}{l}450.6 \pm \\
a^{*} \\
301 \pm 4\end{array}$ & $\begin{array}{l}\text { Concordia } \\
\text { Concordia }\end{array}$ \\
\hline $\begin{array}{l}\text { MN11-117 } \\
\text { MN11-118 } \\
\text { MN11-119 }\end{array}$ & $\begin{array}{l}\text { Gouffre } \\
\text { du } \\
\text { Cerisier } \\
\text { Fine } \\
\text { Grained } \\
\text { Gneiss } \\
\text { Gouffre } \\
\text { du } \\
\text { Cerisier } \\
\text { Fine } \\
\text { Grained } \\
\text { Gneiss } \\
\text { Gouffre } \\
\text { du } \\
\text { Cerisier } \\
\text { Fine } \\
\text { Grained } \\
\text { Gneiss }\end{array}$ & $\begin{array}{l}\mathrm{N} \\
43^{\circ} 35^{\prime} 09^{\prime \prime} \\
\mathrm{E} \\
2^{\circ} 57^{\prime} 30^{\prime \prime} \\
\mathrm{N} \\
43^{\circ} 35^{\prime} 09^{\prime \prime} \\
\mathrm{E} \\
2^{\circ} 57^{\prime} 30^{\prime \prime} \\
\mathrm{N} \\
43^{\circ} 35^{\prime} 09^{\prime}, \\
\mathrm{E} \\
2^{\circ} 57^{\prime} 30^{\prime \prime}\end{array}$ & & $\begin{array}{l}445.8 \pm \\
a \\
441.0 \pm \\
a \\
316.9 \pm \\
a * \\
297.3 \\
\mathrm{Ma} *\end{array}$ & $\begin{array}{l}\text { Mean } \\
{ }^{232} \text { Th age } \\
\text { Concordia } \\
\text { Mean } \\
{ }^{232} \text { Th age } \\
\text { Concordia }\end{array}$ \\
\hline MN11-57 & $\begin{array}{l}\text { Roc du } \\
\text { Caroux } \\
\text { Fine } \\
\text { Grained } \\
\text { Gneiss }\end{array}$ & $\begin{array}{l}\mathrm{N} \\
43^{\circ} 35^{\prime} 09^{\prime \prime} \\
\mathrm{E} \\
2^{\circ} 57^{\prime} 30^{\prime \prime}\end{array}$ & & ${ }_{\text {Ia }} 290.6 \pm$ & Concordia \\
\hline MN11-59 & $\begin{array}{l}\text { Héric } \\
\text { Fine } \\
\text { Grained } \\
\text { Gneiss }\end{array}$ & $\begin{array}{l}\mathrm{N} \\
43^{\circ} 35^{\prime} 45^{\prime \prime} \\
\mathrm{E} \\
2^{\circ} 57^{\prime} 02^{\prime \prime}\end{array}$ & & ${ }_{\mathrm{Ia}} 294.3 \pm$ & Concordia \\
\hline \multicolumn{6}{|c|}{ ESPINOUSE SUBDOME } \\
\hline MN 28 & $\begin{array}{l}\mathrm{C} / \mathrm{S} \\
\text { Piquotalin } \\
\text { Granite }\end{array}$ & $\begin{array}{l}\mathrm{N} \\
43^{\circ} 41^{\prime} 17^{\prime}, \\
\mathrm{E} \\
2^{\circ} 39^{\prime} 33^{\prime \prime}\end{array}$ & & Ia & Concordia \\
\hline MN 5 & $\begin{array}{l}\text { La Planésie } \\
\text { Augen } \\
\text { Gneiss }\end{array}$ & $\begin{array}{l}\mathrm{N} 43^{\circ} 38^{\prime} \\
03^{\prime \prime} \\
\mathrm{E} 2^{\circ} 51^{\prime} \\
13^{\prime \prime}\end{array}$ & $\begin{array}{l}304.5 \pm \\
1 \mathrm{Ma}\end{array}$ & & $\begin{array}{l}\text { Upper } \\
\text { pt age }\end{array}$ \\
\hline MN 27 & $\begin{array}{l}\text { Ste Eutrope } \\
\text { Augen } \\
\text { Gneiss }\end{array}$ & $\begin{array}{l}\mathrm{N} \\
43^{\circ} 39^{\prime} 57^{\prime \prime} \\
\mathrm{E} \\
2^{\circ} 59^{\prime} 03^{\prime \prime}\end{array}$ & & $\mathrm{Ia}_{\mathrm{Ia}} 314.4 \pm$ & Concordia \\
\hline MN 4 & $\begin{array}{l}\text { Candoubre } \\
\text { Fine } \\
\text { Grained } \\
\text { Gneiss }\end{array}$ & 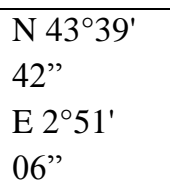 & $\begin{array}{l}301 \pm 7 \\
\mathrm{Ma}\end{array}$ & (Z) $290 \pm$ & $\begin{array}{l}\text { Concordia } \\
\text { Upper } \\
\text { ept age }\end{array}$ \\
\hline
\end{tabular}




\section{Credit Author Statement}

Françoise Roger : Conceptualization, Investigation, Methodology, Writing- Original draft preparation

Christian Teyssier : Conceptualization, Investigation, Methodology, Writing- Original draft preparation

Donna Whitney : Conceptualization, Investigation, Methodology, Writing- Original draft preparation

Jean-Patrick Respaut : Investing, Writing-Rewiew \& Editing

Jean-Louis Paquette : Investing, Resources, Writing-Rewiew \& Editing

Patrice Rey : Investing, Methodology, Writing-Review \& Editing 
Declaration of interest Statement : none

Graphical abstract 


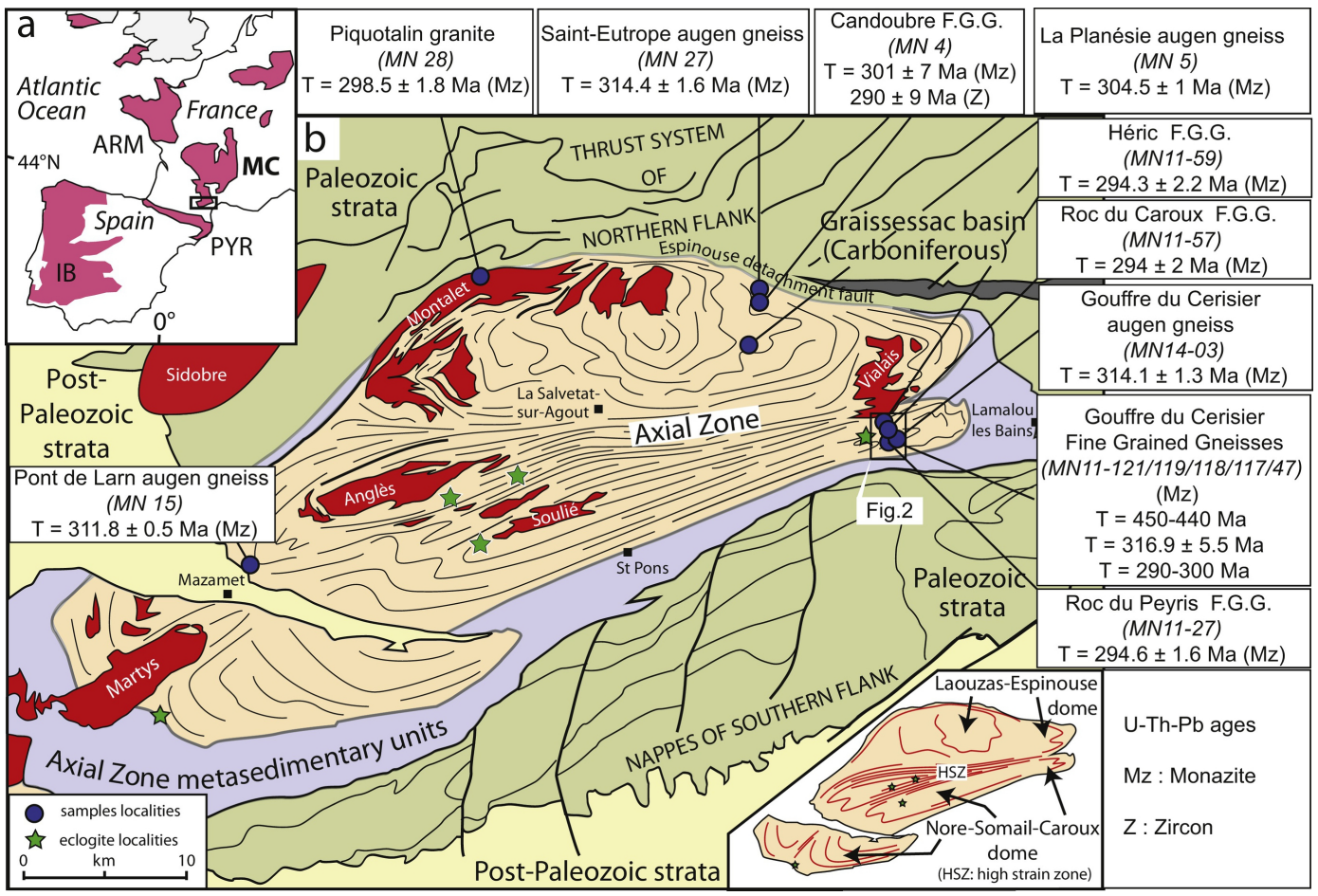

Figure 1 


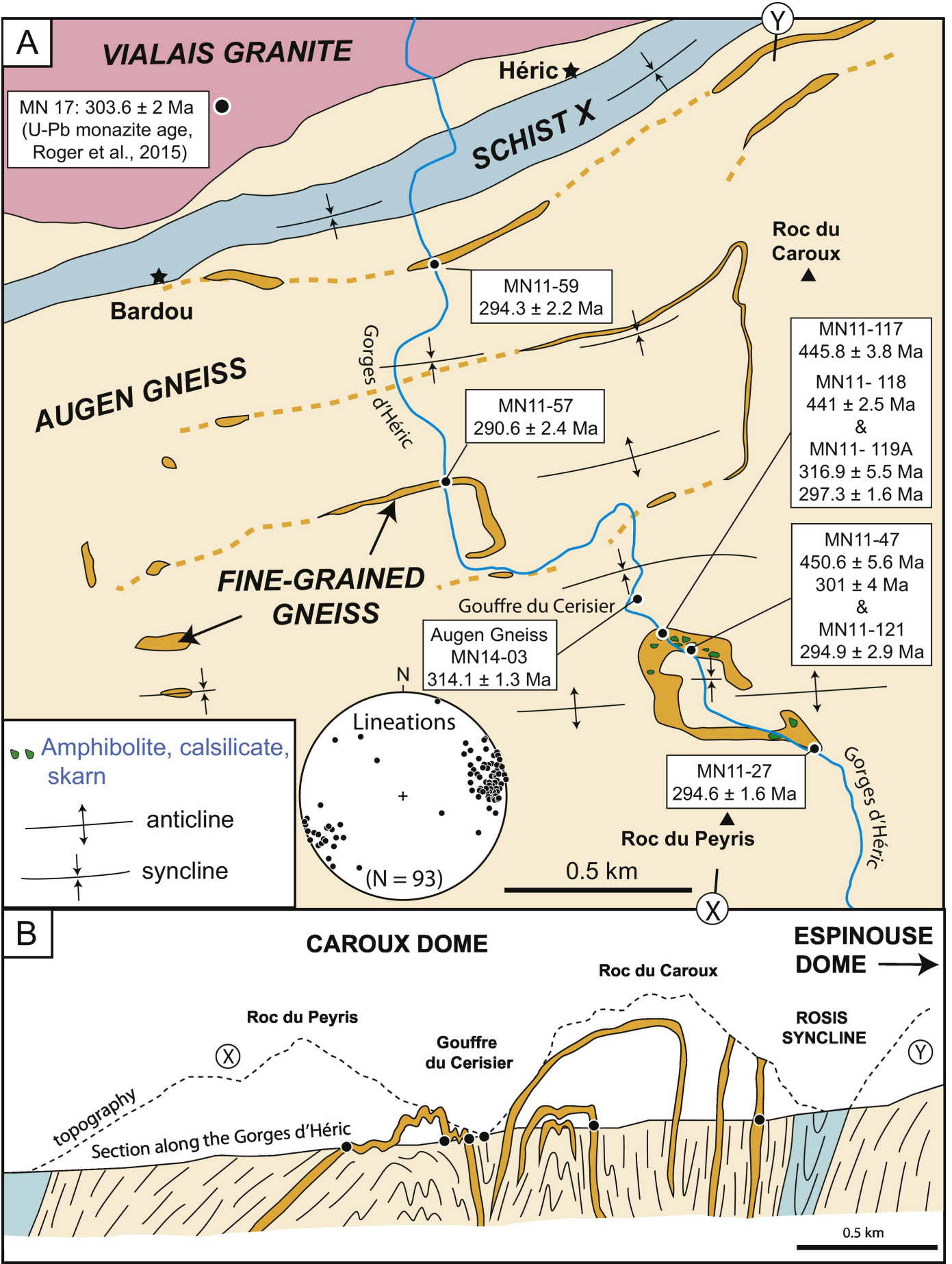




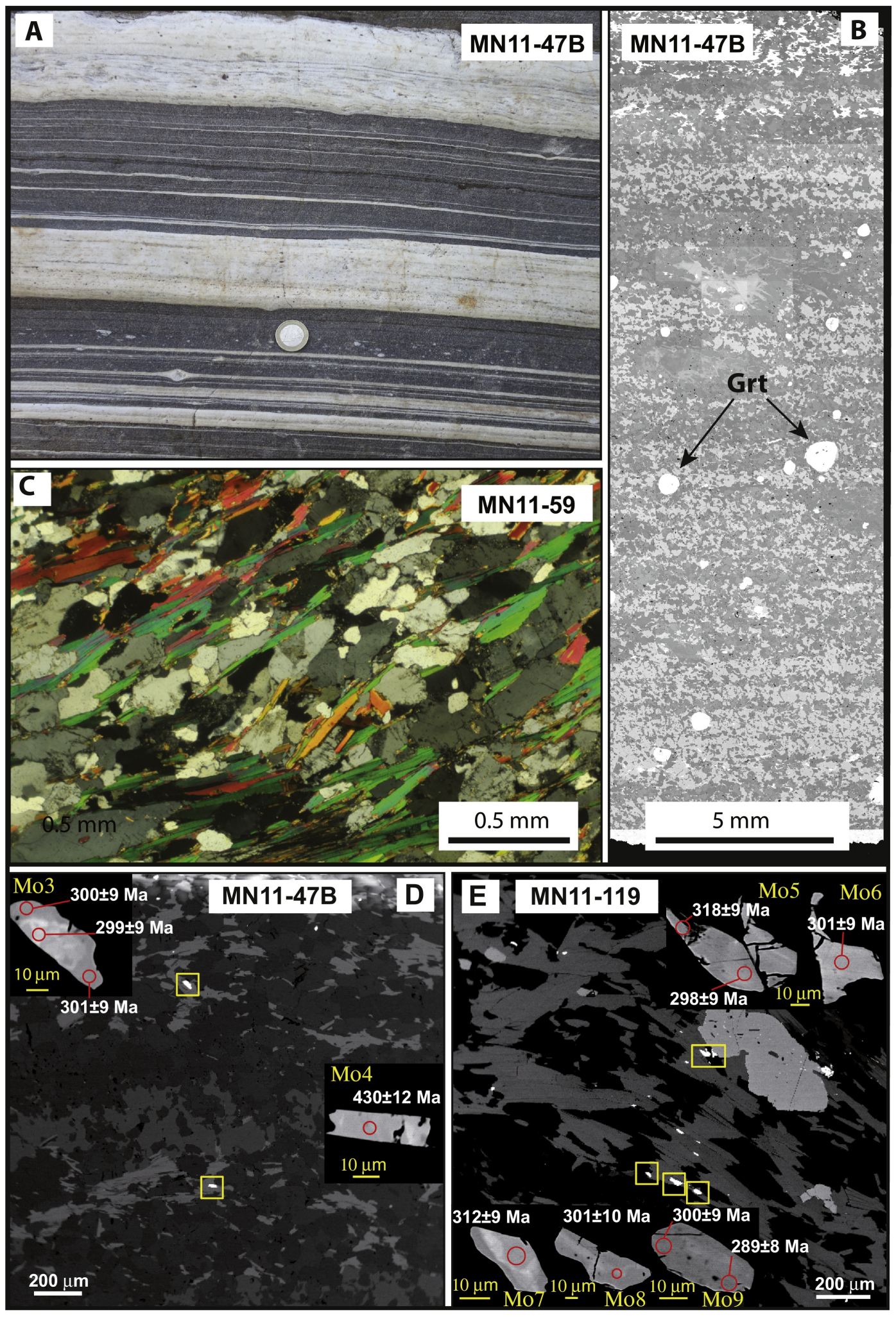




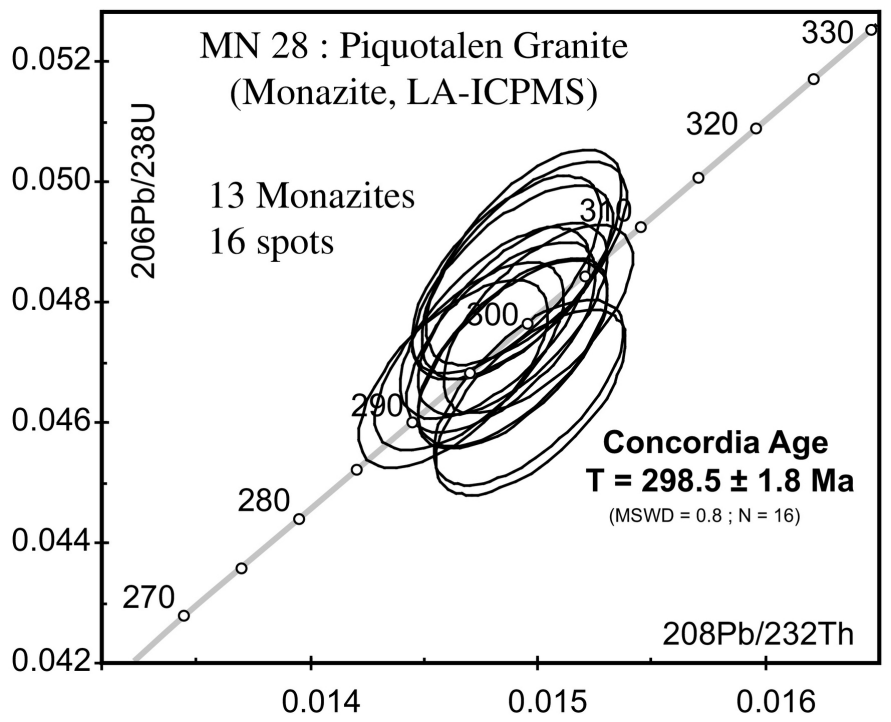

Figure 4 

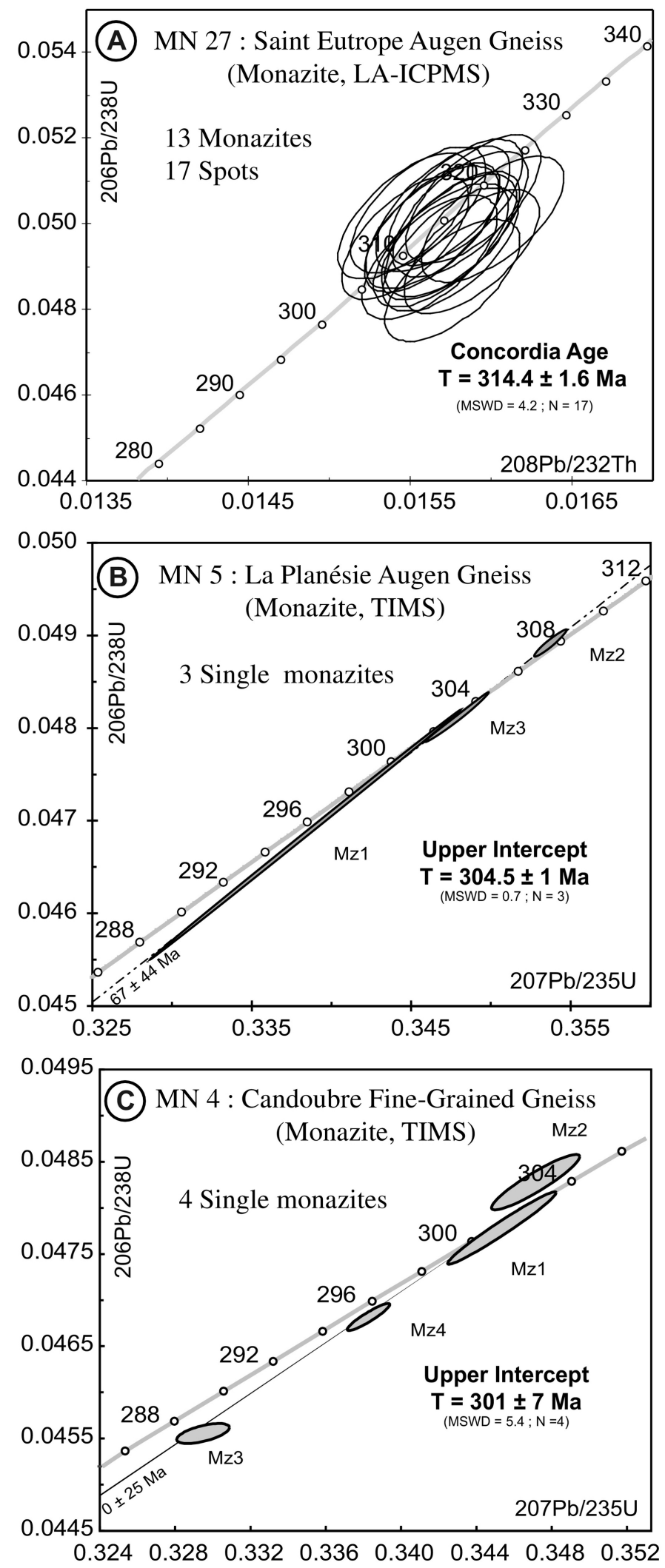


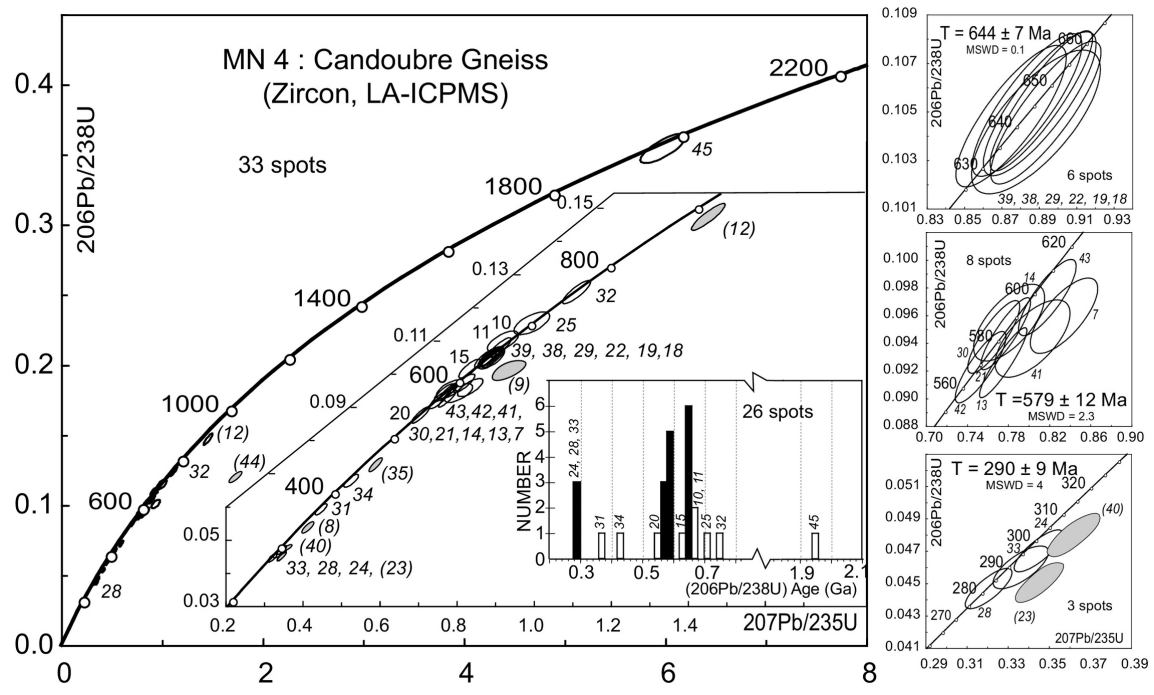

Figure 6 


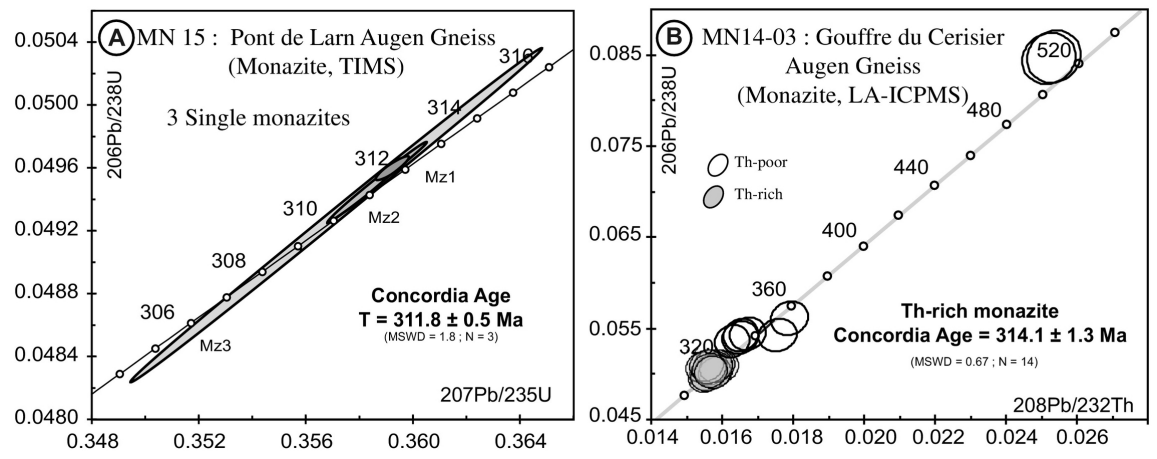

Figure 7 

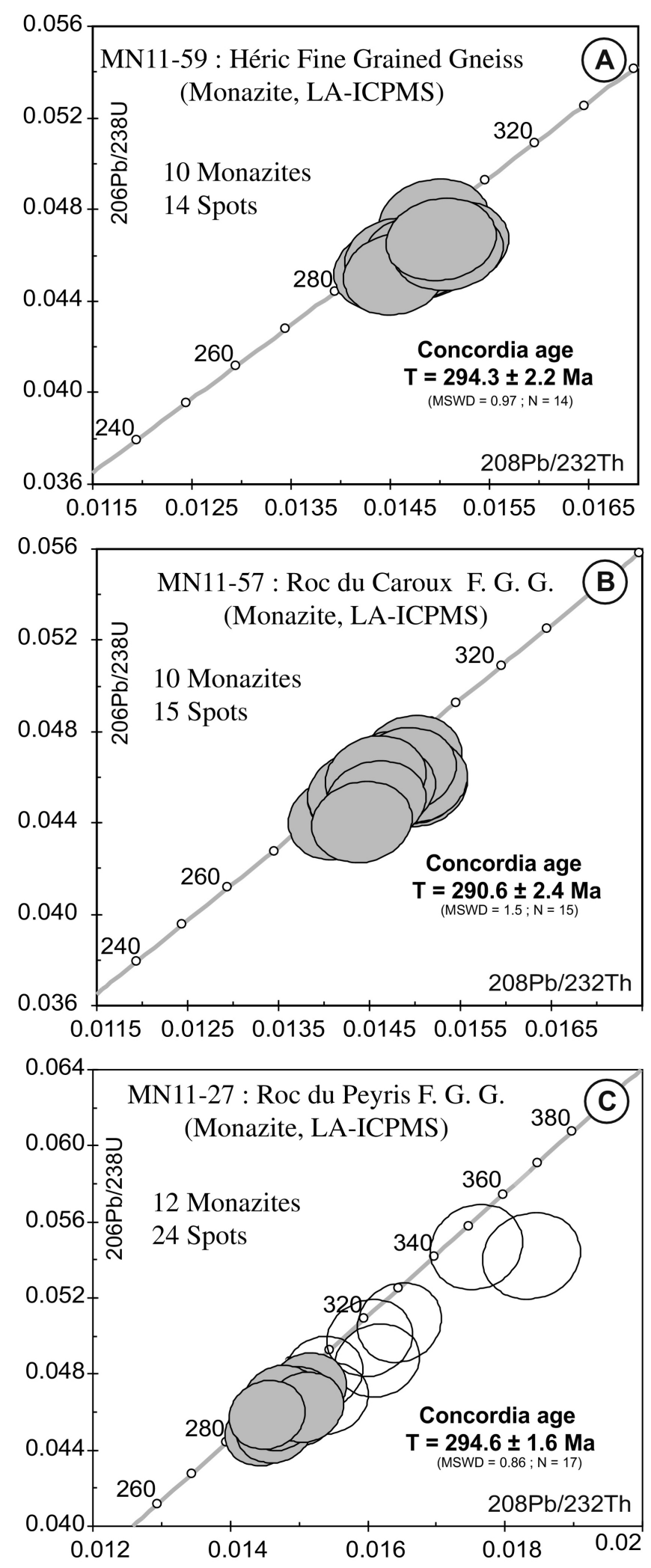

Figure 8 

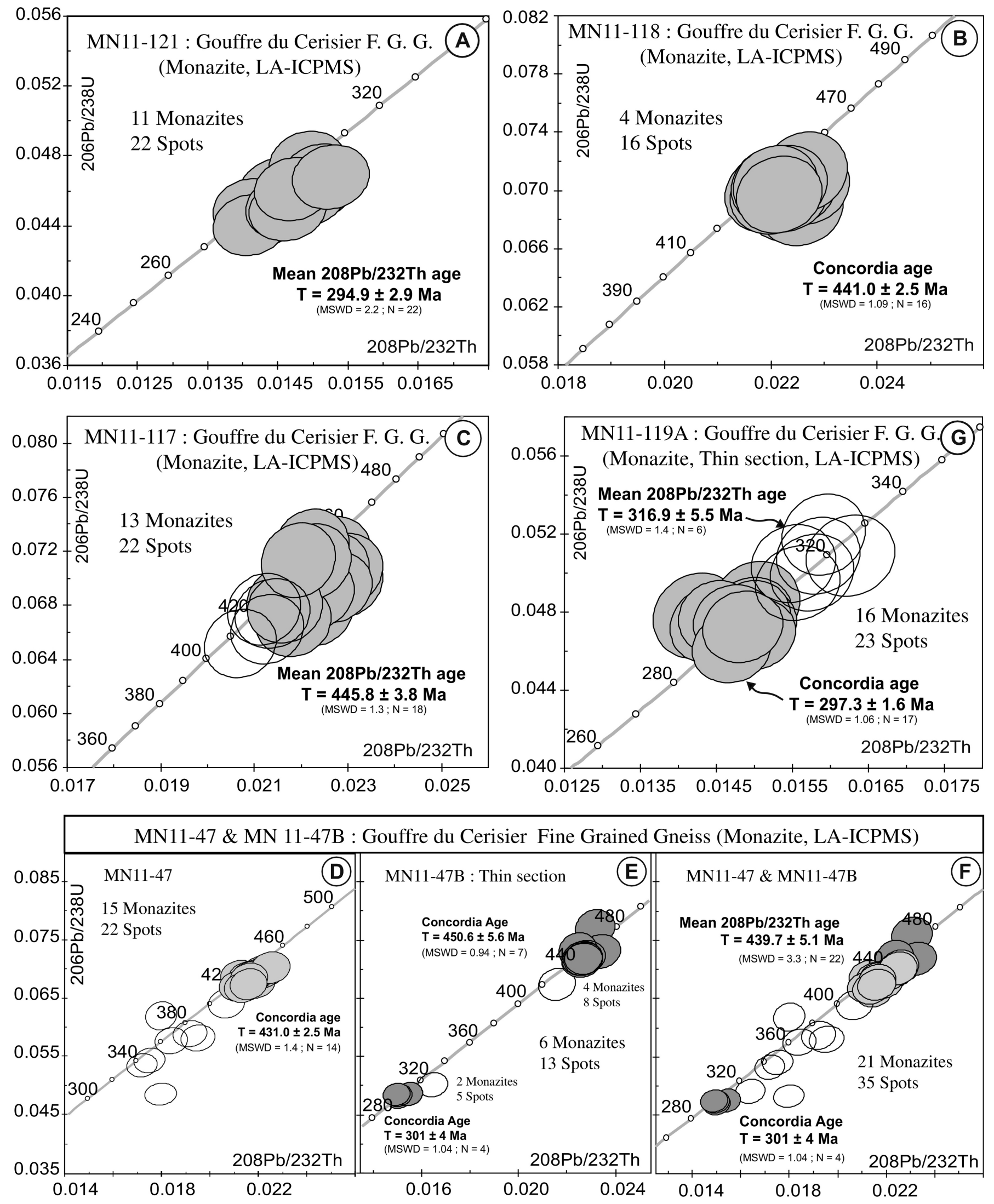


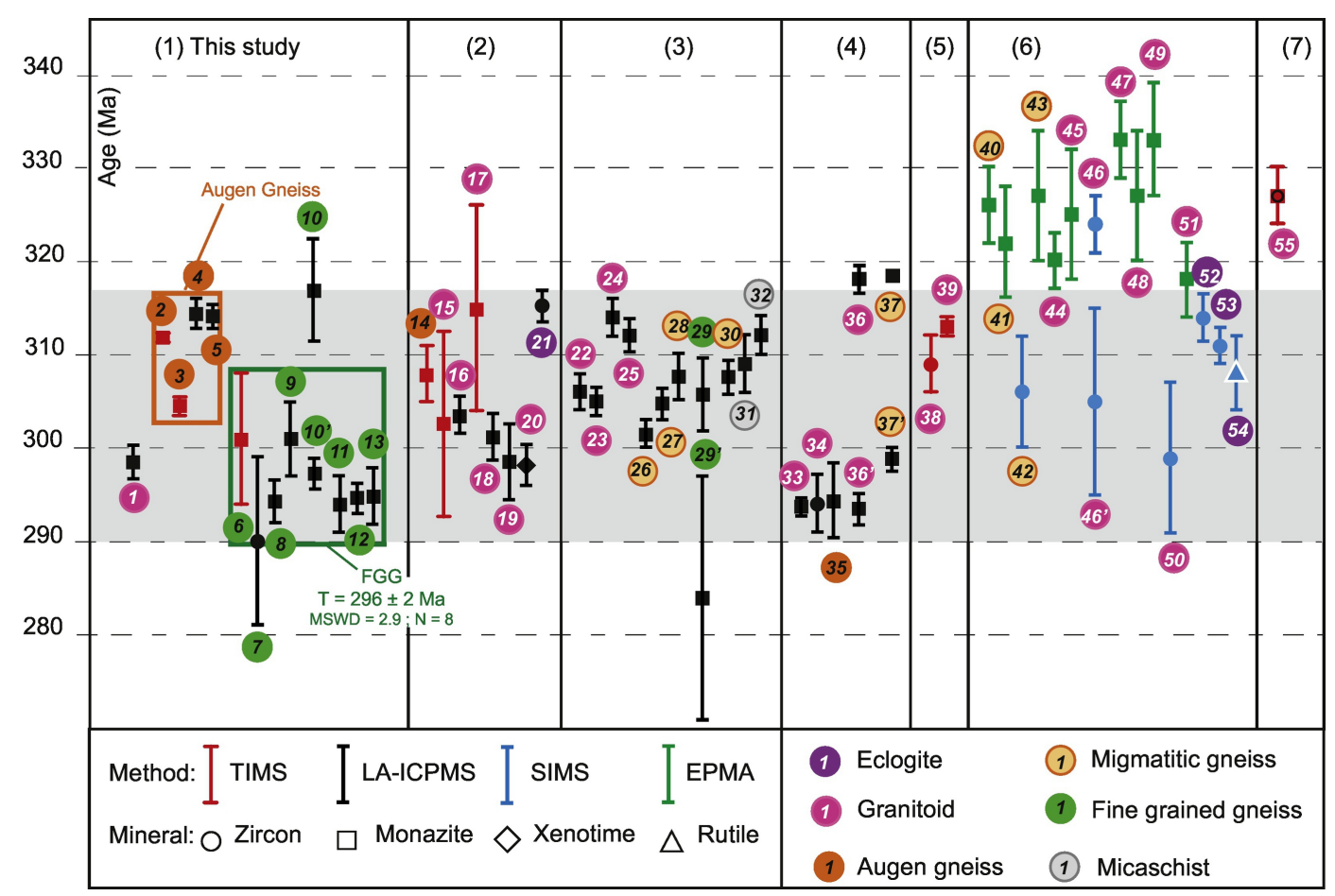

Figure 10 
Piquotalin granite

(4) $294 \pm 1 \mathrm{Ma} \mathrm{(Mz)}$ $294 \pm 3 \mathrm{Ma}(\mathrm{Z})$

(1) $298.5 \pm 1.8 \mathrm{Ma}$ (Mz)

Montalet granite

(6) $333 \pm 4 \mathrm{Ma}(\mathrm{Mz})$ $327 \pm 7 \mathrm{Ma}(\mathrm{Mz})$ $324 \pm 3 \mathrm{Ma}(\mathrm{Z})$

(2) $305 \pm 10 \mathrm{Ma}(\mathrm{Z})$

Laouzas granite

(6) $333 \pm 6 \mathrm{Ma} \mathrm{(Mz)}$ $299 \pm 8(Z)$

(4) $318 \pm 1.4 \mathrm{Ma} \mathrm{(Mz)}$ $293.5 \pm 1.7 \mathrm{Ma}(\mathrm{Mz})$

La Salvetat metatextite

(6) $327 \pm 7(\mathrm{Mz})$

$306 \pm 6(\mathrm{Z})$

(3) $307.6 \pm 1.8 \mathrm{Ma}(\mathrm{Mz})$ Migmatite

(4) $318.5 \pm 0.7 \mathrm{Ma}(\mathrm{Mz})$ $298.8 \pm 1.3 \mathrm{Ma}(\mathrm{Mz})$

\section{Eclogite \\ (2) $359.5 \pm 4.7 \mathrm{Ma}^{*}(Z)$ $315.2 \pm 1.6 \mathrm{Ma}(\mathrm{Z})$ \\ (6) $314 \pm 2.5 \mathrm{Ma}(\mathrm{Z})$ $311 \pm 2 \mathrm{Ma}(\mathrm{Z})$ $308 \pm 4 \mathrm{Ma}(\mathrm{R})$ \\ Pont de Larn augen gneiss (1) $311.8 \pm 0.5 \mathrm{Ma}$ (Mz)}

(3) Martys granite $314+2 \mathrm{Ma}(\mathrm{Mz})$

- samples localities

samples (this study) 饮 eclogite localities 0 $\mathrm{km}$
(3) Cabot metatexite $301.5 \pm 1.4 \mathrm{Ma}(\mathrm{Mz})$

(3) Crd-granitic dyke $312.1 \pm 1.8 \mathrm{Ma}(\mathrm{Mz})$ $304.7 \pm 1.7 \mathrm{Ma}(\mathrm{Mz})$
Candoubre F.G.G. (1) $301 \pm 7 \mathrm{Ma}(\mathrm{Mz})$ $290 \pm 9 \mathrm{Ma}(\mathrm{Z})$
Ste Eutrope

(1) augen gneiss

$314.4 \pm 1.6 \mathrm{Ma}(\mathrm{Mz})$

(4) $\mathrm{C} / \mathrm{S}$ augen gneiss $294 \pm 4 \mathrm{Ma}(\mathrm{Mz})$
La Planésie augen gneiss

(1)

$304.5 \pm 1 \mathrm{Ma}(\mathrm{Mz})$
Espinouse

migmatitic gneiss

(3)

$307.7 \pm 2.5 \mathrm{Ma}(\mathrm{Mz})$

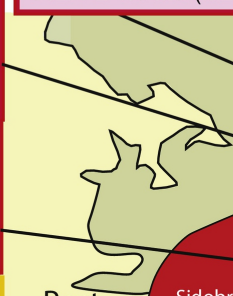

Post-

Paleozoic

strata
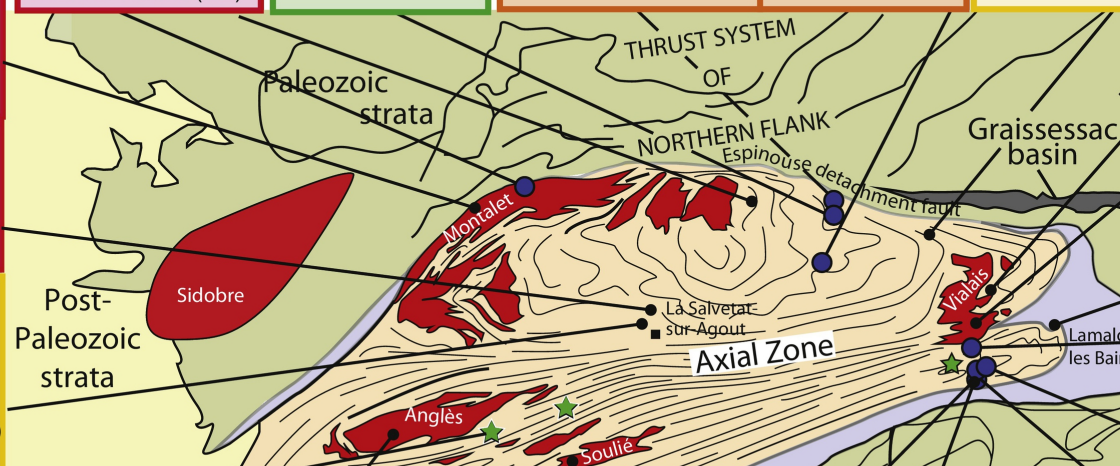

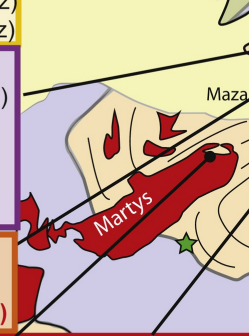

Anglès granite

(3) $305 \pm 1.5 \mathrm{Ma}(\mathrm{Mz})$ (6) $325 \pm 7 \mathrm{Ma}(\mathrm{Mz})$

(1) This study

(2) Roger et al. (2015) \& Withney et al. (2016)

(3) Trap et al. (2016)

(4) Poilvet et al. (2011), Pitra et al. (2012) \& Poujol et al. (2016)

\section{Ourtigas}

(6) migmatitic gneiss $458 \pm 9 \mathrm{Ma}^{*}(\mathrm{Mz})$

$326 \pm 4 \mathrm{Ma}(\mathrm{Mz})$

(2) undeformed Gt-granite $299 \pm 4 \mathrm{Ma}(\mathrm{Mz})$

$298 \pm 2 \mathrm{Ma}(\mathrm{X})$

Vialais granite

(2) $304 \pm 2 \mathrm{Ma}(\mathrm{Mz})$

$301 \pm 2 \mathrm{Ma}(\mathrm{Mz})$

(6) $320 \pm 3(\mathrm{Mz})$

(7) $327 \pm 3(Z)$

(3) La Fage F.G.G.

$305.7 \pm 3.9 \mathrm{Ma}(\mathrm{Mz})$

Héric F.G.G.

(1) $294.3 \pm 2.2 \mathrm{Ma}(\mathrm{Mz})$

Gorges d'Héric F. G. G. (1) (Mz)

455-440 Ma*

$316.9 \pm 5.5 \mathrm{Ma}^{*}$

$294 \pm 2 \mathrm{Ma}$

$297.3 \pm 1.6 \mathrm{Ma}$

$301 \pm 4 \mathrm{Ma}$

$294.9 \pm 2.9 \mathrm{Ma}$

$294.6 \pm 1.6 \mathrm{Ma}$

$\mathrm{U}-\mathrm{Th}-\mathrm{Pb}$ ages

$300 \mathrm{Ma}$ : LA-ICPMS

$300 \mathrm{Ma}$ : TIMS

$300 \mathrm{Ma}:$ SIMS

300 Ma: EPMA

* inherited age

$(\mathrm{Mz})$ : Monazite (Z): Zircon

$(\mathrm{X})$ : Xenotime

(R): Rutile

\begin{tabular}{|c|}
\hline Migmatitic gneiss \\
\hline $\begin{array}{l}\text { Fine Grained Gneiss } \\
\text { (F.G.G.) }\end{array}$ \\
\hline Micaschist \\
\hline
\end{tabular}




\section{(A) Variscan granites $(n=17)$}

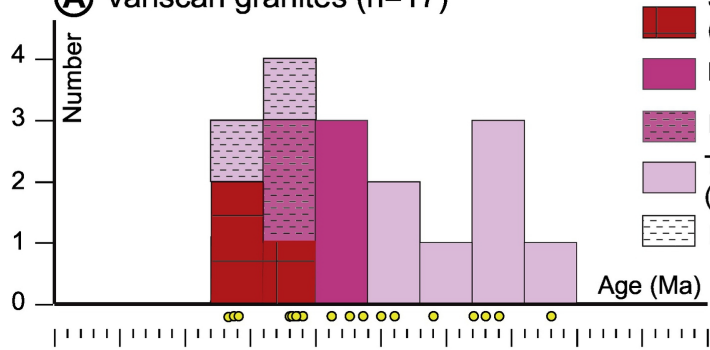
280285

(B) Metamorphic rocks $(n=29)$

$$
\begin{aligned}
& 6 \\
& 5 \\
& 4 \\
& 3 \\
& 2 \\
& 1 \\
& 0
\end{aligned}
$$

6
5
4
$3-$
2
1
0
Syn-kinematic Piquotalin/Montalet granite (with $\mathrm{S} / \mathrm{C}$ structures) $(\mathrm{T}=295 \pm 6 \mathrm{Ma}, \mathrm{n}=3$ )

Late kinematic Vialais granite ( $T=303 \pm 2 \mathrm{Ma}, \mathrm{n}=3$ )

Post-kinematic Ourtigas granite ( $T=298 \pm 2 \mathrm{Ma}, \mathrm{n}=2$ )

The other syn-kinematic granites

(e.g. Anglès, Soulié, Laouzas granites) $(T=303-319 \mathrm{Ma}, \mathrm{n}=7$ )

Probably fluid-related event (Laouzas granite)

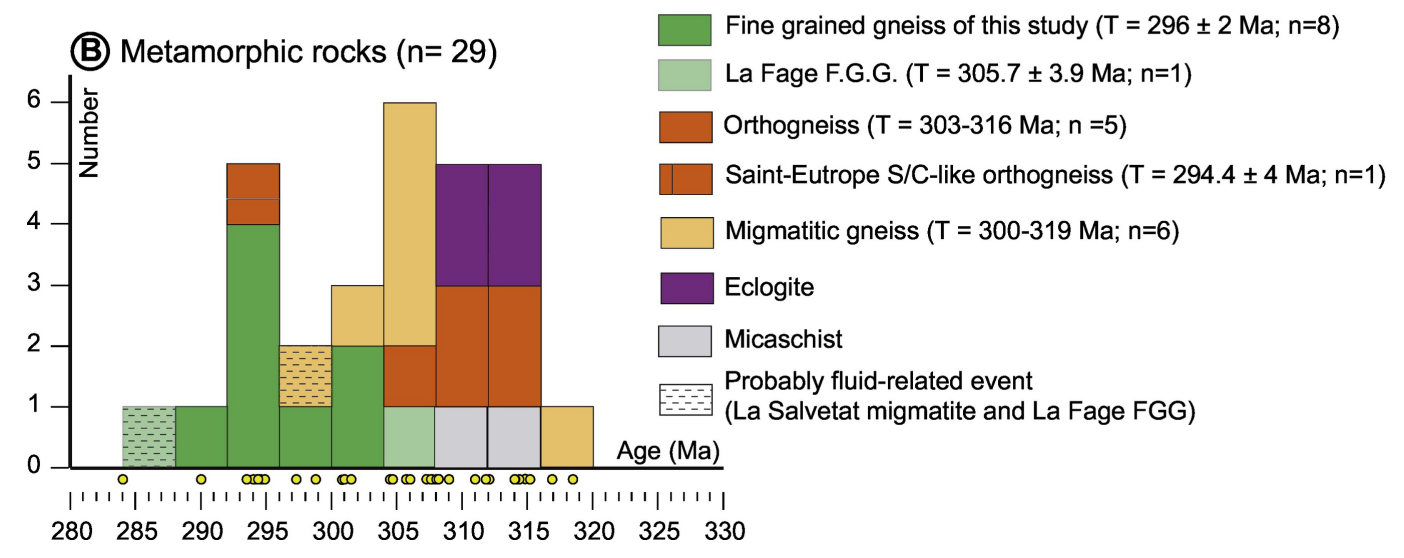

Figure 12 
A

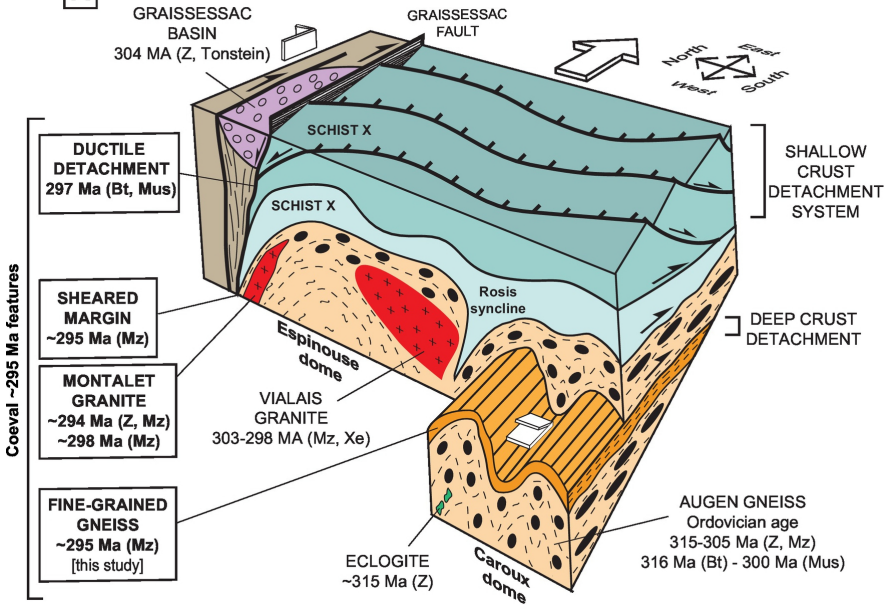

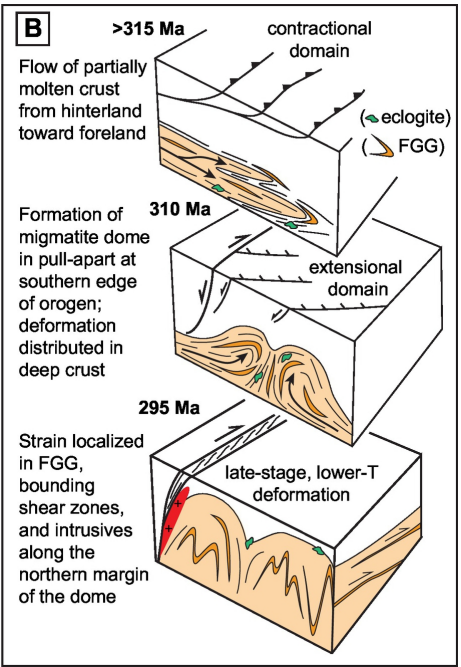

Figure 13 


\section{Candoubre Fine Grained Gneiss (MN4)}

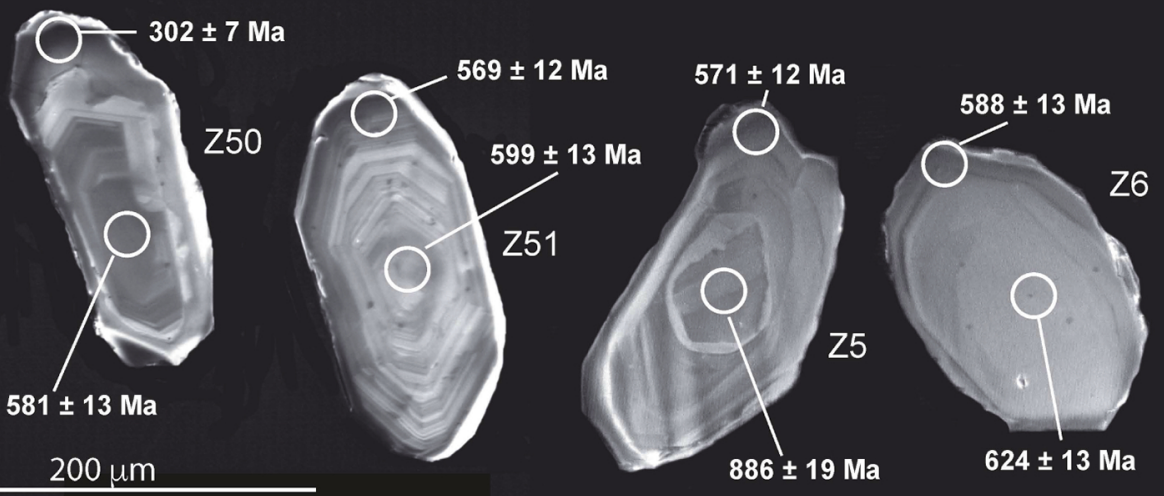

\section{Gouffre du Cerisier}

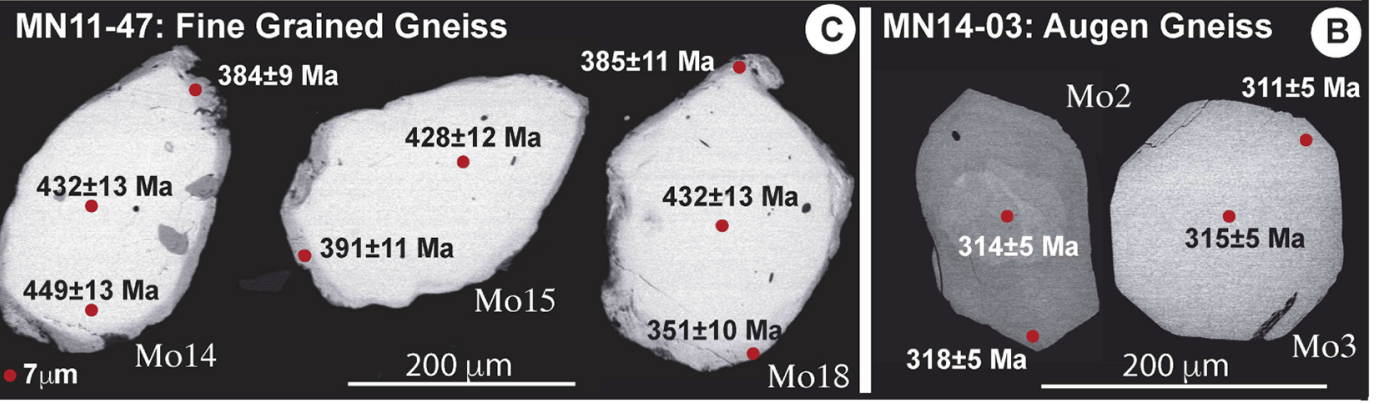

Figure 14 